\title{
Inositol 1,4,5-Triphosphate Drives Glutamatergic and Cholinergic Inhibition Selectively in Spiny Projection Neurons in the Striatum
}

\author{
Michael A. Clements, Immani Swapna, and Hitoshi Morikawa \\ Waggoner Center for Alcohol and Addiction Research, Section of Neurobiology, University of Texas, Austin, Austin, Texas 78712
}

\begin{abstract}
The striatum is critically involved in the selection of appropriate actions in a constantly changing environment. The spiking activity of striatal spiny projection neurons (SPNs), driven by extrinsic glutamatergic inputs, is shaped by local GABAergic and cholinergic networks. For example, it is well established that different types of GABAergic interneurons, activated by extrinsic glutamatergic and local cholinergic inputs, mediate powerful feedforward inhibition of SPN activity. In this study, using mouse striatal slices, we show that glutamatergic and cholinergic inputs exert direct inhibitory regulation of SPN activity via activation of metabotropic glutamate receptors (mGluRs) and muscarinic acetylcholine receptors. While pressure ejection of the group I mGluR (mGluR1/5) agonist DHPG [(S)-3,5dihydroxyphenylglycine] equally engages both mGluR1 and mGluR5 subtypes, the mGluR-dependent component of IPSCs elicited by intrastriatal electrical stimulation is almost exclusively mediated by the mGluR1 subtype. $\mathrm{Ca}^{2+}$ release from intracellular stores specifically through inositol 1,4,5-triphospahte receptors $\left(\mathrm{IP}_{3} \mathrm{Rs}\right)$ and not ryanodine receptors (RyRs) mediates this form of inhibition by gating two types of $\mathrm{Ca}^{2+}$-activated $\mathrm{K}^{+}$channels (i.e., small-conductance SK channels and large-conductance BK channels). Conversely, spike-evoked $\mathrm{Ca}^{2+}$ influx triggers $\mathrm{Ca}^{2+}$ release solely through RyRs to generate SK-dependent slow afterhyperpolarizations, demonstrating functional segregation of $\mathrm{IP}_{3} \mathrm{Rs}$ and RyRs. Finally, $\mathrm{IP}_{3}$-induced $\mathrm{Ca}^{2+}$ release is uniquely observed in SPNs and not in different types of interneurons in the striatum. These results demonstrate that $\mathrm{IP}_{3}$-mediated activation of $\mathrm{SK}$ and $\mathrm{BK}$ channels provides a robust mechanism for glutamatergic and cholinergic inputs to selectively suppress striatal output neuron activity.
\end{abstract}

\section{Introduction}

The output from the striatum to downstream basal ganglia structures plays a critical role in the selection and planning of actions (Graybiel et al., 1994). Medium-sized, GABAergic spiny projection neurons (SPNs), which constitute $\sim 95 \%$ of striatal neurons, provide the sole output of the striatum. In vivo intracellular recordings have revealed that membrane potential of SPNs shifts from a quiescent hyperpolarized DOWN state (approximately -70 to $-90 \mathrm{mV}$ ) to a depolarized UP state (approximately -50 to $-60 \mathrm{mV}$ ), during which action potential (AP) firing occurs (Wilson and Kawaguchi, 1996; Stern et al., 1998). Coordinated excitatory inputs mainly from the cerebral cortex drive the transition to the UP state, which lasts for hundreds of milliseconds to seconds before switching back to the DOWN state. During the UP state, the balance between depolarizing cortical and thalamic inputs and hyperpolarizing voltage-gated $\mathrm{K}^{+}$conductances, together with inputs from local GABAergic and cholinergic net-

\footnotetext{
Received Oct. 8, 2012; revised Nov. 21, 2012; accepted Dec. 19, 2012.

Author contributions: M.A.C., I.S., and H.M. designed research; M.A.C. and I.S. performed research; M.A.C., I.S., and H.M. analyzed data; M.A.C., I.S., and H.M. wrote the paper.

This work was supported by NIH Grants DA015687 and AA015521. We thank Dr. Kamran Khodakhah for the generous gift of caged $\mathbb{I P}_{3}$ made in his laboratory. We also thank Dr. Mark Harnett for critical comments on this manuscript.

Correspondence should be addressed to Hitoshi Morikawa, Section of Neurobiology, University of Texas, Austin, 2400 Speedway, PAT 402, Austin, TX 78712. E-mail: morikawa@utexas.edu.

DOI:10.1523/JNEUROSCI.4759-12.2013

Copyright $\odot 2013$ the authors $\quad 0270-6474 / 13 / 332697-12 \$ 15.00 / 0$
}

works, are thought to determine whether and when SPNs fire APs (Surmeier et al., 2007; Tepper et al., 2008). Single-unit recordings in behaving animals have shown that SPNs differentially exhibit increases and decreases, or pauses, in firing before and during performance of actions (Hikosaka et al., 1989; Jin and Costa, 2010; Krause et al., 2010). However, the underlying mechanisms of the pauses and whether they can occur in the UP state or represent transitions to the DOWN state remain unclear.

SPN firing is also shaped by two types of $\mathrm{Ca}^{2+}$-activated $\mathrm{K}^{+}$channels, small-conductance SK channels and largeconductance BK channels (Pineda et al., 1992; Hopf et al., 2010). $\mathrm{Ca}^{2+}$ influx through voltage-gated $\mathrm{Ca}^{2+}$ channels (VGCCs) triggered by each AP activates these channels, thereby generating afterhyperpolarizations (AHPs) that control AP duration and interspike intervals. AP-evoked $\mathrm{Ca}^{2+}$ transients can be further amplified by a process called $\mathrm{Ca}^{2+}$-induced $\mathrm{Ca}^{2+}$ release $(\mathrm{CICR})$ via two types of $\mathrm{Ca}^{2+}$-sensitive receptors [i.e., inositol 1,4,5trisphosphate receptors ( $\mathrm{IP}_{3} \mathrm{Rs}$ ) and ryanodine receptors (RyRs)] located on intracellular $\mathrm{Ca}^{2+}$ stores (Berridge, 1998). Furthermore, neurotransmitter inputs coupled to G-protein-dependent generation of second messengers elicit $\mathrm{IP}_{3} \mathrm{R}-$ and/or RyRdependent $\mathrm{Ca}^{2+}$ release to activate SK and BK channels in a variety of neurons in the CNS (Fiorillo and Williams, 2000; Morikawa et al., 2003; Gulledge and Stuart, 2005; Canepari and Ogden, 2006; Hagenston et al., 2008; Power and Sah, 2008; ElHassar et al., 2011). Although group I metabotropic glutamate receptors (mGluRs) (mGluR1/5) and the $\mathrm{M}_{1}$-subtype of musca- 

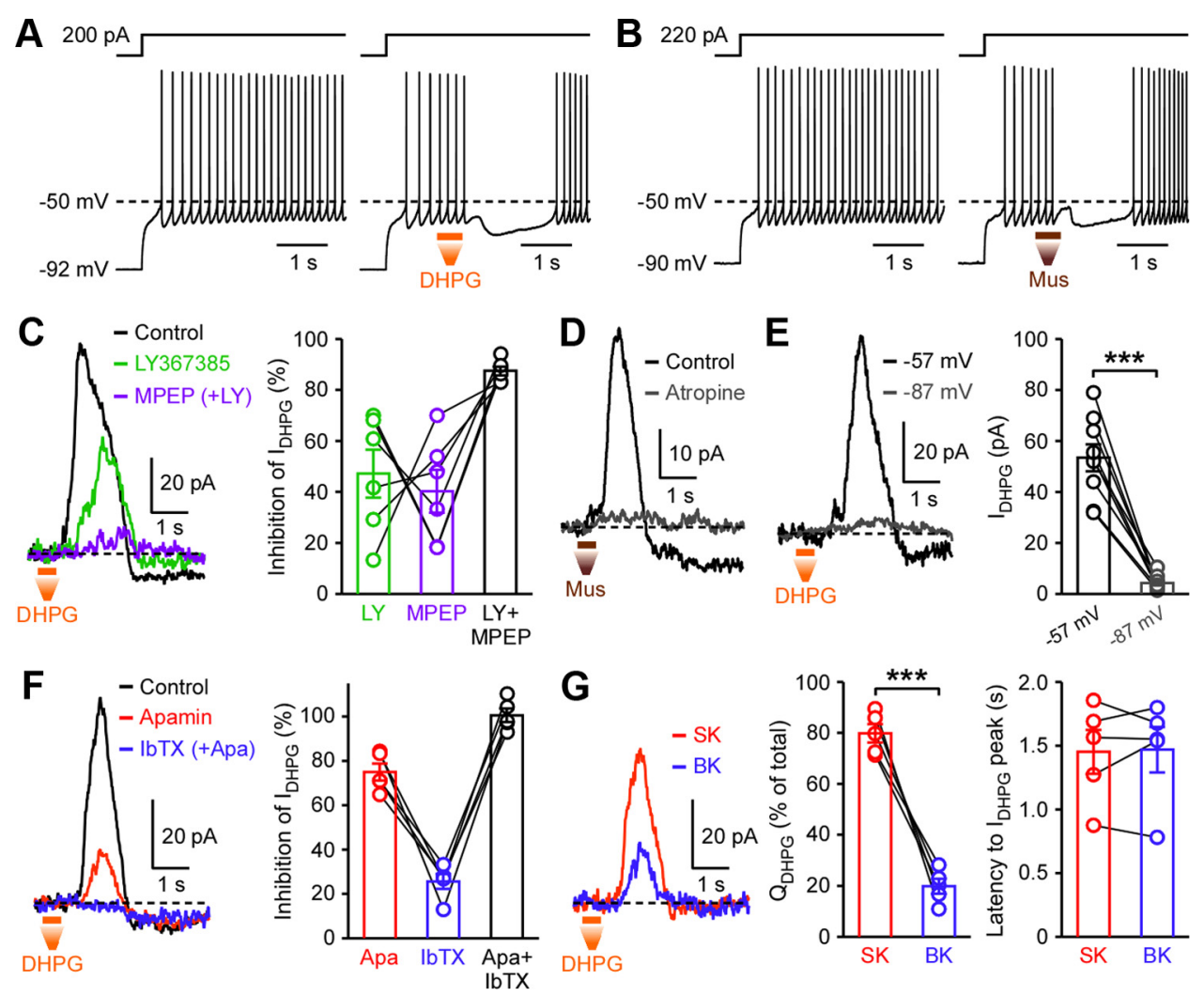

Figure 1. Transient $m G$ luR and $m A C h R$ activation produces pauses in SPN firing and activates SK and BK channels. $A, B$, Example traces depicting DHPG- and muscarine-induced pauses in SPN firing evoked by depolarizing current injections. Local pressure ejection $(500 \mathrm{~ms})$ of DHPG $(100 \mu \mathrm{M})(\boldsymbol{A})$ or muscarine $(100 \mu \mathrm{M})(\boldsymbol{B})$ was made at the time indicated. $\boldsymbol{C}$, Example traces and summary graph showing the effects of LY367385 $(75 \mathrm{~nm})$ and MPEP $(50 \mathrm{nM})$ on $I_{\text {DHPG }}\left(V_{\mathrm{h}}=-57 \mathrm{mV}\right)$. D. Example traces illustrating the effect of atropine $(2 \mu \mathrm{M})$ on muscarine-evoked currents. $\boldsymbol{E}$, Representative traces and summary graph showing that $I_{\text {DHPG }}$ was suppressed by hyperpolarization to $-87 \mathrm{mV}\left(t_{(8)}=9.24,{ }^{* * *} p<0.0001\right.$; paired $t$ test). $F$, Example traces and summary graph depicting the effects of apamin $(100 \mathrm{~nm})$ and IbTX (100 nM) on DHPG $_{\text {. }}$, Left, Traces of the apamin-sensitive SK-dependent component and the IbTX-sensitive BK-dependent component of DHPG $_{\text {DHP }}$ shown in $\boldsymbol{F}$. These traces were obtained by subtracting traces before and after apamin/lbTX applications. Right, Summary graphs plotting the fraction of charge carried by SK-and BK-dependent components $\left(t_{(4)}=9.68{ }^{* * *} p<0.001\right.$; paired $t$ test $)$ and the latency to peak after the onset of DHPG pressure ejection. Error bars indicate SEM.

rinic acetylcholine receptors ( $\mathrm{mAChRs}$ ), which are coupled to the phospholipase C (PLC)-IP 3 cascade, are expressed in virtually all SPNs (Yan et al., 2001; Gubellini et al., 2004), the role of $\mathrm{Ca}^{2+}$ store-dependent activation of SK and BK channels in regulating SPN activity has yet to be determined.

In this study, using mouse striatal slices, we show that the mGluR/ $\mathrm{mAChR} \rightarrow \mathrm{IP}_{3} \mathrm{R} \rightarrow \mathrm{SK} / \mathrm{BK}$ channel pathway produces powerful suppression of depolarization-evoked SPN firing, while the AP $\rightarrow$ RyR $\rightarrow$ SK channel pathway dominates the slow component of AHPs. Furthermore, our data showing the absence of $\mathrm{IP}_{3}$-induced $\mathrm{Ca}^{2+}$ release in striatal interneurons imply that $\mathrm{IP}_{3}$ signaling plays a privileged role in glutamatergic and cholinergic inputdependent inhibitory regulation of striatal output neurons.

\section{Materials and Methods}

Animals. Male C57BL/6J mice (3-4 weeks of age) were obtained from The Jackson Laboratory and were housed under a $12 \mathrm{~h}$ light/dark cycle. Food and water were available ad libitum. All animal procedures were approved by the University of Texas Institutional Animal Care and Use Committee.

Electrophysiology. Mice were killed by cervical dislocation under isoflurane anesthesia, and oblique horizontal slices $\left(\sim 20-30^{\circ}, 200-250\right.$ $\mu \mathrm{m})$ containing the dorsal striatum were cut in an ice-cold solution containing the following (in mM): 205 sucrose, $2.5 \mathrm{KCl}, 1.25 \mathrm{NaH}_{2} \mathrm{PO}_{4}$, $7.5 \mathrm{MgCl}_{2}, 0.5 \mathrm{CaCl}_{2}, 10$ glucose, and $25 \mathrm{NaHCO}_{3}$, saturated with $95 \%$ $\mathrm{O}_{2}$ and $5 \% \mathrm{CO}_{2}(\sim 300 \mathrm{mOsm} / \mathrm{kg})$ and incubated $>1 \mathrm{~h}$ at $35^{\circ} \mathrm{C}$ in a solution containing the following (in $\mathrm{mM}$ ): $126 \mathrm{NaCl}, 2.5 \mathrm{KCl}, 1.2$ $\mathrm{NaH}_{2} \mathrm{PO}_{4}, 1.2 \mathrm{MgCl}_{2}, 2.4 \mathrm{CaCl}_{2}, 11$ glucose, and $25 \mathrm{NaHCO}_{3}$, saturated with $95 \% \mathrm{O}_{2}$ and $5 \% \mathrm{CO}_{2}, \mathrm{pH} 7.4, \sim 295 \mathrm{mOsm} / \mathrm{kg}$. Recordings were made at $34-35^{\circ} \mathrm{C}$ in the same solution perfused at $\sim 2.5 \mathrm{ml} / \mathrm{min}$.

Cells were visualized using an upright microscope (Olympus) with infrared/oblique illumination optics. Whole-cell recordings were made with borosilicate glass pipettes $(2.2-2.8 \mathrm{M} \Omega$ ) filled with internal solution containing the following (in $\mathrm{mM}$ ): $115 \mathrm{~K}$-gluconate, $20 \mathrm{KCl}, 1.5 \mathrm{MgCl}_{2}$, 10 HEPES, 0.025 EGTA, $2 \mathrm{Mg}$-ATP, $0.2 \mathrm{Na}_{2}$-GTP, and $10 \mathrm{Na}_{2}-$ phosphocreatine, $\mathrm{pH} 7.2, \sim 285 \mathrm{mOsm} / \mathrm{kg}$, unless indicated otherwise. Series resistance was continuously monitored but left uncompensated during voltage-clamp recording experiments. Recordings were discarded if the series resistance increased beyond $20 \mathrm{M} \Omega$. Bridge balance was adjusted periodically (approximately every $2-3 \mathrm{~min}$ ) during current-clamp recording experiments. The membrane potential was corrected for a liquid junction potential of $-7 \mathrm{mV}$. A Multiclamp 700B amplifier (Molecular Devices) and AxoGraph X software (AxoGraph Scientific) were used to record and collect data (filtered at $0.5-2 \mathrm{kHz}$ and digitized at $1-5 \mathrm{kHz}$ for voltageclamp recordings; filtered at $10 \mathrm{kHz}$ and digitized at $20 \mathrm{kHz}$ for currentclamp recordings). The majority of experiments were performed in the presence of picrotoxin $(100 \mu \mathrm{M})$ to block $\mathrm{GABA}_{\mathrm{A}}$ inputs.

For pressure ejection, patch pipettes $(\sim 2 \mu \mathrm{m}$ tip diameter $)$ were filled with (S)-3,5-dihydroxyphenylglycine (DHPG) $(100 \mu \mathrm{M})$ or muscarine chloride $(100 \mu \mathrm{M})$, and pressure of 20 psi was applied using a TooheySpritzer Pressure System IIe to eject the drug. Synaptic responses were evoked with a bipolar tungsten electrode in the presence of DNQX $(20 \mu \mathrm{M})$ and picrotoxin $(100 \mu \mathrm{M})$ to block AMPA and $\mathrm{GABA}_{\mathrm{A}}$ receptors and slices were preincubated with MK-801 $(10 \mu \mathrm{M})$ to block NMDA receptors.

Flash photolysis. Cells were dialyzed with caged $\mathrm{IP}_{3}(400 \mu \mathrm{M})$ through the whole-cell pipette for 15-20 min after break-in. A brief UV flash $(\sim 1$ 

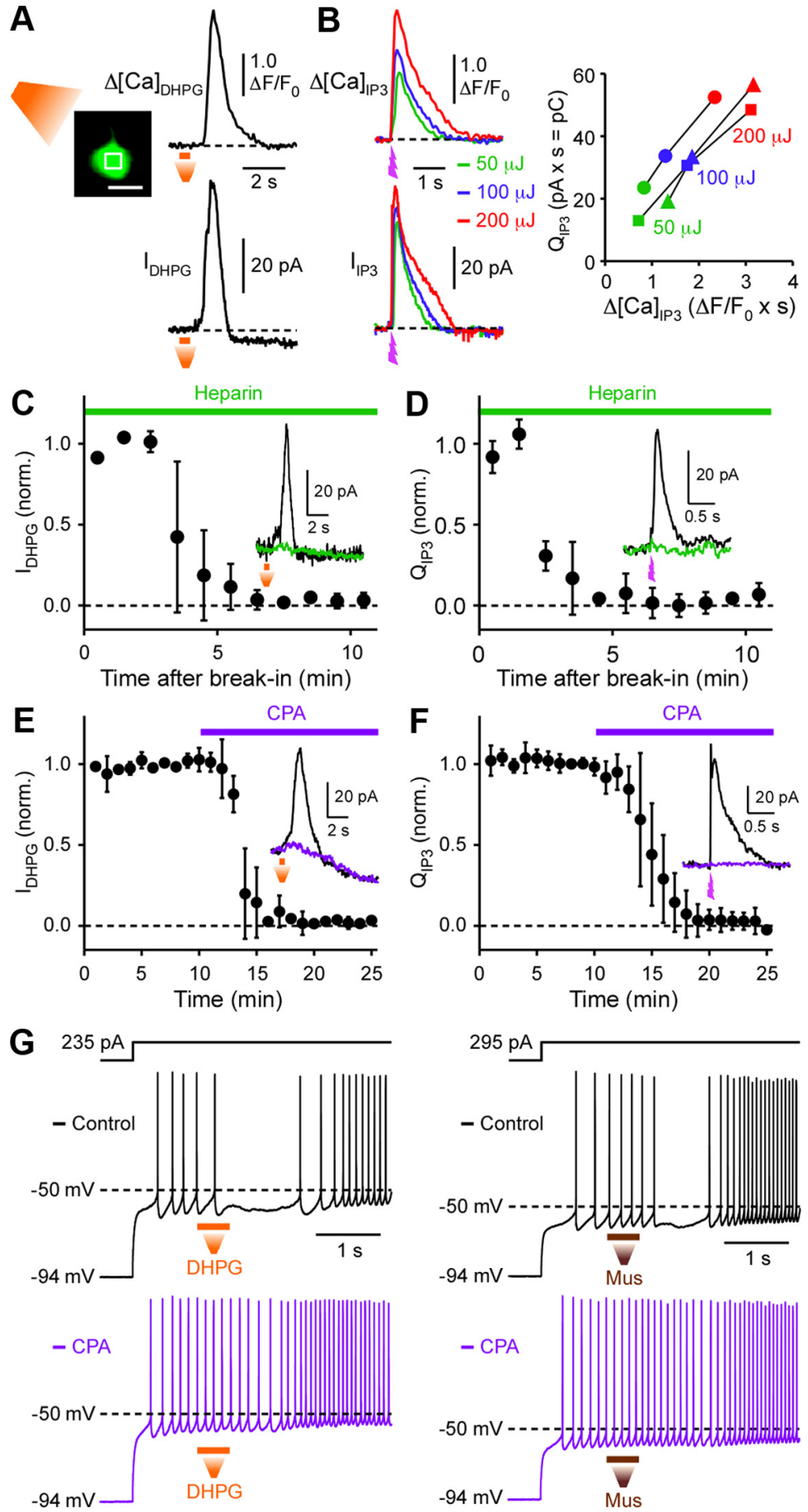

Figure 2. $\quad I P_{3} R$-dependent $\mathrm{Ca}^{2+}$ release from intracellular stores mediates mGluR/mAChR-induced SPN inhibition. $\boldsymbol{A}$, Representative experiment imaging DHPG-evoked $\mathrm{Ca}^{2+}$ transient. Fluorescence change, monitored at the ROI indicated on the left (scale bar: $10 \mu \mathrm{m}$ ), and an outward current evoked by pressure ejection of DHPG (100 $\mu \mathrm{m}$; in a pipette placed $\sim 60 \mu \mathrm{m}$ from the recorded cell) are shown in an SPN loaded with Fluo-4FF (100 $\mu \mathrm{m})$. Note that DHPG-evoked delayed inward current, which is independent of $\mathrm{Ca}^{2+}$ rise, outlasts the fluorescence change. $\boldsymbol{B}$, Example experiment monitoring $\mathrm{Ca}^{2+}$ transients and outward currents elicited by flash photolysis of caged $\mathrm{IP}_{3}(400 \mu \mathrm{m})$ using three different UV flash intensities $(50,100$, and $200 \mu \mathrm{J})$. UV flashes were applied at the time indicated. Fluorescence changes were measured at the ROI placed in the soma as in $\boldsymbol{A}$ (cell image not shown). Right, The total charge transfer of $I_{\text {IP3 }}$ (termed $Q_{\mid P 3}$ ) exhibited approximately linear relationship with the total fluorescence change (integrated over time) in three cells tested for different UV intensities. Fluo-4FF $(100 \mu \mathrm{m})$ was used to monitor $\left[\mathrm{Ca}^{2+}\right]_{\mathrm{i}}$ in these three cells. $C-F$, Summary time graphs showing that cytosolic application of heparin $(1 \mathrm{mg} / \mathrm{ml})$ or bath application of CPA $(20 \mu \mathrm{m})$ abolished outward currents elicited by DHPG $(\boldsymbol{C}, \boldsymbol{E})$ and $\mathrm{IP}_{3}(\boldsymbol{D}, \boldsymbol{F})$. Traces from a sample experiment are shown as an inset in each panel. $\boldsymbol{G}$, Example traces depicting that CPA suppressed the pauses in SPN firing produced by pressure ejection of DHPG (left) and muscarine (right). Note that DHPG and muscarine still caused delayed acceleration in firing after CPA treatment. ms) was applied with a xenon arc lamp driven by a photolysis system (Cairn Research) to rapidly photolyze caged $\mathrm{IP}_{3}(\sim 3 \mathrm{~ms})$ (Walker et al., 1989). The UV flash was focused through a $60 \times$ objective onto a $350 \mu \mathrm{m}$ area surrounding the recorded cell. The Cairn system has the capacity to vary the intensity of UV flash, which was measured at the tip of the objective (expressed in microjoules). The degree of photolysis of caged compounds is known to be proportional to the UV flash intensity (McCray et al., 1980). The maximal UV flash intensity was $\sim 180-250 \mu \mathrm{J}$ with our system, depending on the age of the xenon arc lamp at the time of experiments.

$\mathrm{Ca}^{2+}$ imaging. Fluorescence imaging of $\left[\mathrm{Ca}^{2+}\right]_{\mathrm{i}}$ was mostly done using Fluo-4FF (Invitrogen) as $\mathrm{Ca}^{2+}$ indicators. Some of the imaging experiments were performed with Fluo-4 or Fluo-5F. These $\mathrm{Ca}^{2+}$ indicators were loaded into the cell via the whole-cell pipette. Images were taken at $15 \mathrm{~Hz}$ using the Olympus Disk Spinning Unit Imaging System. After raw fluorescent signals from selected regions of interest (ROIs) were background subtracted at each time point, $\mathrm{Ca}^{2+}$ transients were expressed as $\Delta F / F_{0}=\left(F(t)-F_{0}\right) / F_{0}$, where $F_{0}$ was determined as an average of $F(t)$ over a $1 \mathrm{~s}$ baseline period. Brief artifacts accompanying UV flashes are omitted from the fluorescence traces in flash photolysis experiments.

Drugs. Apamin, iberiotoxin, cyclopiazonic acid, DHPG, $(S)-(+)$ - $\alpha$-amino-4-carboxy-2methylbenzeneacetic acid (LY367385), MPEP, $\left[\mathrm{S}-\left(\mathrm{R}^{*}, \mathrm{R}^{*}\right)\right]-[3-[[1-(3,4-$ dichlorophenyl)ethyl] amino]-2-hydroxypropyl] (cyclohexylmethyl) phosphinic acid (CGP54626), DNQX, and picrotoxin were obtained from Tocris Biosciences. TTX was obtained from Alomone Labs. Fluo-4, Fluo-5F, and Fluo-4FF were purchased from Invitrogen. Caffeine, heparin sodium salt (from porcine intestinal mucosa), and muscarine chloride were obtained from Sigma RBI. Caged $\mathrm{IP}_{3}$ was a generous gift from Dr. Kamran Khodakhah (Albert Einstein College of Medicine, Bronx, NY).

Data analysis. AP parameters were obtained from the first APs evoked during depolarizing current injections. AP threshold was determined as the point where the first derivative of the membrane potential $(d v / d t)$ exceeded 20 $\mathrm{V} / \mathrm{s}$. AP half-width was measured at the potential halfway between AP threshold and peak. AHP amplitude was determined as the amount of hyperpolarization from AP threshold.

Data are expressed as mean \pm SEM. Statistical significance was determined by Student's $t$ test or ANOVA followed by Bonferroni post hoc test. The difference was considered significant at $p<0.05$.

\section{Results}

Transient $m$ GluR and $\mathrm{mAChR}$ stimulation inhibits SPN activity and activates $\mathrm{SK}$ and BK channels To examine the effects of transient mGluR and $\mathrm{mAChR}$ activation on the firing of SPNs, whole-cell current-clamp record- 

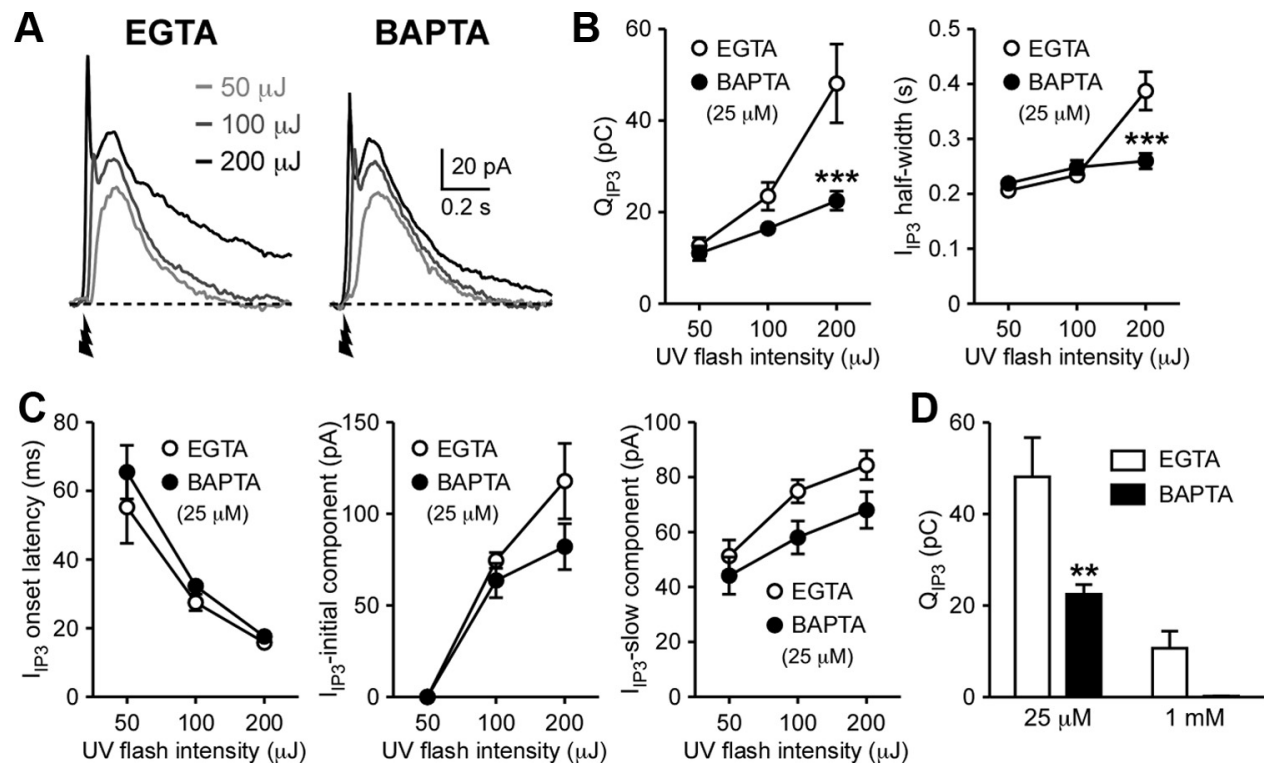

Figure 3. $\quad \mathbb{P}_{3}$ triggers BAPTA-sensitive localized $\mathrm{Ca}^{2+}$ signaling. $A$, Representative traces of $I_{\mid \mathrm{P} 3}$ using three different UV intensities $(50,100$, and $200 \mu \mathrm{J})$ in cells filled with EGTA $(25 \mu \mathrm{M})$ and BAPTA $(25 \mu \mathrm{M})$. UV flashes were applied at the time indicated. $B$, Summary plots showing the effects of BAPTA on $Q_{1 P 3}\left(\mathrm{Ca}^{2+}\right.$ buffer type: $F_{(1,16)}=6.22, p<0.05 ; \mathrm{Ca}^{2+}$ buffer concentration: $F_{(2,16)}=36.2, p<0.0001 ; \mathrm{Ca}^{2+}$ buffer type by concentration: $\left.F_{(2,16)}=10.1, p<0.01\right)$ and $I_{\text {IP3 }}$ half-width $\left(\mathrm{Ca}^{2+}\right.$ buffer concentration: $F_{(2,16)}=37.8, p<0.0001 ; \mathrm{Ca}^{2+}$ buffer type by concentration: $F_{(2,16)}=18.9, p<0.0001$; mixed two-way ANOVA).*** $p<0.001$ versus EGTA (Bonferroni's post hoc test). C, Summary graphs plotting three parameters of $I_{\text {IP3 }}$ (onset latency, peak amplitude of the initial component, and peak amplitude of the late component) using three different UV flash intensities in cells filled with EGTA (25 $\mu \mathrm{M})$ or BAPTA (25 $\mu \mathrm{M})$. These parameters were not significantly affected by BAPTA. D, Summary bar graph showing the effects of two different concentrations ( $25 \mu \mathrm{m}$ and $1 \mathrm{~mm})$ of EGTA and BAPTA on $Q_{\mathbb{1 P 3}}\left(200 \mu \mathrm{J}\right.$ UV intensity) (Ca ${ }^{2+}$ buffer type: $F_{(1,14)}=11.7, p<0.01 ; \mathrm{Ca}^{2+}$ buffer concentration: $F_{(1,14)}=32.0, p<0.0001$; two-way ANOVA). ${ }^{* *} p<0.01$ versus EGTA (Bonferroni's post hoc test). Error bars indicate SEM.

ings of these neurons were made in the dorsal striatum and AP firing was evoked by depolarizing current injections (200-350 $\mathrm{pA}$; adjusted to produce $\sim 5-7 \mathrm{~Hz}$ firing). Local pressure ejection (500 ms) of the group I mGluR (mGluR1/5) agonist DHPG (100 $\mu \mathrm{M}$ in a pipette placed $\sim 50-80 \mu \mathrm{m}$ from the recorded cell) produced a transient hyperpolarization and a pause in firing lasting $1.85 \pm 0.11 \mathrm{~s}$, followed by a delayed increase in the firing frequency, in eight cells tested (Fig. 1A). When DHPG application was made at the resting membrane potential (approximately -80 to $-95 \mathrm{mV}$ ) in six of these eight cells, no measurable response was observed. Pressure ejection of muscarine (100 $\mu \mathrm{M} ; 500 \mathrm{~ms})$, a broad-spectrum mAChR agonist, also caused membrane hyperpolarization and a pause in SPN firing $(1.38 \pm 0.15 s ; n=5)$, followed by gradual acceleration of firing (Fig. $1 B$ ).

In voltage clamp $\left(V_{\mathrm{h}}=-57 \mathrm{mV}\right)$, pressure ejection of DHPG (100 $\mu \mathrm{M}, 500 \mathrm{~ms}$, once a minute) produced transient outward currents $(\sim 1-2 s)$, which were followed by prolonged inward currents ( $\sim 20-50 \mathrm{~s}$ ) (Fig. 1C). Bath perfusion of the mGluR1 antagonist LY367385 (75 nM) and the mGluR5 antagonist MPEP (50 nM) suppressed DHPG-induced outward currents (termed $\left.I_{\mathrm{DHPG}}\right)$ by $47 \pm 9$ and $40 \pm 8 \%$, respectively, in six cells where these two antagonists were sequentially applied (three cells: LY367385 $\rightarrow$ MPEP + LY367385; three cells: MPEP $\rightarrow$ LY367385 + MPEP), indicating that these two mGluR subtypes make relatively equal contributions. LY367385 and MPEP similarly inhibited DHPG-induced delayed inward currents by $44 \pm 7$ and $51 \pm 6 \%$, respectively. Pressure ejection of muscarine also produced transient outward currents followed by inward currents, which were abolished by the general $\mathrm{mAChR}$ antagonist atropine $(2 \mu \mathrm{M})(n=3$; Fig. $1 D)$.

Group I mGluRs and mAChRs are coupled to $\mathrm{Ca}^{2+}$-activated SK channels in many different types of neurons in other brain areas (Fiorillo and Williams, 2000; Morikawa et al., 2003; Gulledge and Stuart, 2005; Hagenston et al., 2008; Power and Sah,
2008; El-Hassar et al., 2011) and to BK channels in cerebellar Purkinje neurons (Canepari and Ogden, 2006). Indeed, $I_{\text {DHPG }}$ amplitude was dramatically reduced when the holding potential was hyperpolarized to $-87 \mathrm{mV}$ (Fig. $1 E$ ), consistent with the involvement of $\mathrm{K}^{+}$conductance. Thus, we examined the effects of the SK channel blocker apamin (100 nM) and the BK channel blocker iberiotoxin (IbTX) (100 nM) on $I_{\text {DHPG }}$. Apamin and IbTX reduced the peak amplitude of $I_{\text {DHPG }}$ by $75 \pm 4$ and $26 \pm 3 \%$, respectively, and combined application of apamin and IbTX eliminated $I_{\mathrm{DHPG}}$ without affecting delayed inward currents $(n=$ 5; three cells: apamin $\rightarrow$ IbTX + apamin; two cells: IbTX $\rightarrow$ apamin + IbTX) (Fig. 1F). Accordingly, the apamin-sensitive SK-dependent component accounted for the majority ( $80 \pm 4 \%)$ of charge transfer mediating $I_{\text {DHPG }}$ (Fig. 1G). SK- and BKdependent components reached their peak amplitude with similar latency after DHPG application, suggesting that both types of $\mathrm{Ca}^{2+}$-gated channels may be activated by the same $\mathrm{Ca}^{2+}$ signals. Therefore, transient activation of mGluR1/5 and mAChRs activates $\mathrm{Ca}^{2+}$-sensitive SK and BK channels to regulate SPN excitability. DHPG- and muscarine-induced delayed inward currents were also depressed by membrane hyperpolarization (Fig. 1E), suggesting that they result from closure of $\mathrm{K}^{+}$conductance.

\section{$\mathrm{IP}_{3} \mathrm{R}$-dependent $\mathrm{Ca}^{2+}$ release from intracellular stores mediates SPN inhibition}

When intracellular $\mathrm{Ca}^{2+}\left(\left[\mathrm{Ca}^{2+}\right]_{\mathrm{i}}\right)$ was monitored at the soma with the low-affinity $\left(K_{\mathrm{d}}=9.7 \mu \mathrm{M}\right)$ indicator Fluo-4FF $(100 \mu \mathrm{M})$, local pressure ejection of DHPG produced a rise in $\left[\mathrm{Ca}^{2+}\right]_{\mathrm{i}}$ that coincided with $I_{\text {DHPG }}(n=7)$ (Fig. $\left.2 A\right)$. We next made rapid application of $\mathrm{IP}_{3}$ directly into the cytosol using UV photolysis of caged $\mathrm{IP}_{3}(400 \mu \mathrm{M}$; dialyzed into the cytosol through the wholecell pipette). Photolytic $\mathrm{IP}_{3}$ application produced a transient rise in $\left[\mathrm{Ca}^{2+}\right]_{\mathrm{i}}$ and an outward current (termed $I_{\mathrm{IP} 3}$ ) in a concentration-dependent manner when three different UV flash 
A

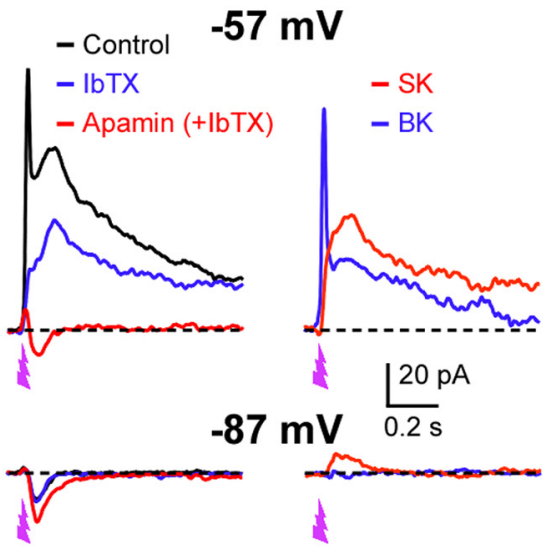

B $340 \mathrm{pA}$
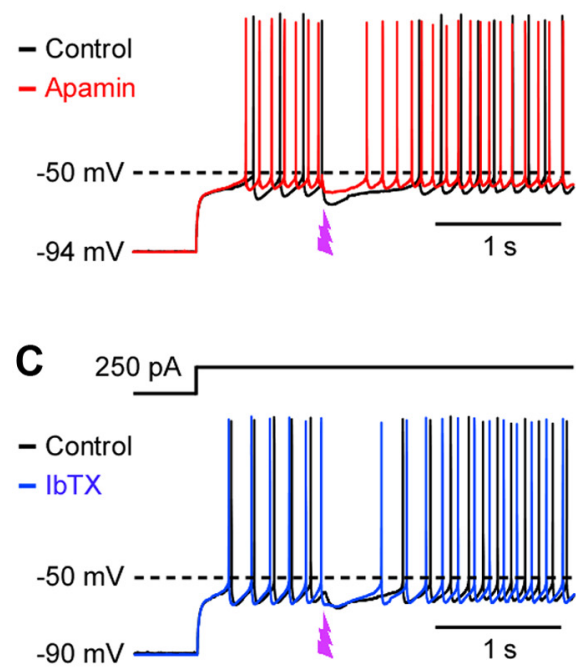

$-90 \mathrm{mV}$

$1 \mathrm{~s}$

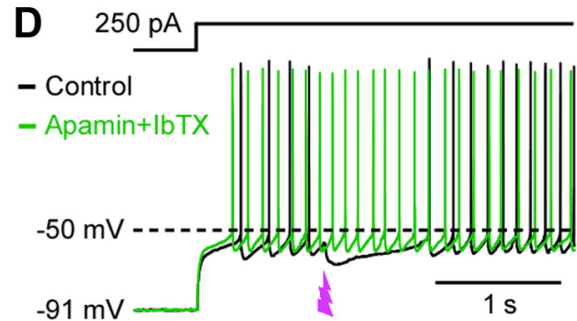

Figure 4. $\quad \mathbb{P}_{3}$-induced activation of SKand BK channels causes SPN inhibition. $A$, Example traces showing the effects of apamin $(100 \mathrm{~nm})$ and IbTX (100 nM) on $I_{\mathbb{P} 3}(200 \mu \mathrm{J}$ UV intensity) measured at -57 and $-87 \mathrm{mV}$. Traces of SK-and BK-dependent components were obtained by subtracting traces before and after apamin/lbTX applications. Note the absence of BK component at $-87 \mathrm{mV}$, reflecting the voltage dependence of BK activation (Fakler and Adelman, 2008). Right, Summary graph plotting the fraction of charge carried by SK- and BK-dependent components at $-57 \mathrm{mV}\left(t_{(4)}=4.04, p<0.05\right.$; paired $t$ test). $\boldsymbol{B}, \boldsymbol{C}$, Example traces depicting the effects of apamin $(\boldsymbol{B})$ and IbTX $(C)$ on $\mathbb{P}_{3}$-induced pause in SPN firing. The duration of $\mathbb{I}_{3}$-induced pause before and after application of apamin $\left(t_{(3)}=9.06 ; p<\right.$ $0.01)$ or IbTX ( $t_{(4)}=2.27, p<0.05$; paired $t$ test) is plotted on the right. $\boldsymbol{D}$, Example traces showing that combined application of apamin and IbTX eliminated the $\mathrm{IP}_{3}$-induced pause. ${ }^{*} p<0.05,{ }^{* *} p<0.01$. Error bars indicate SEM.

intensities $(50,100$, and $200 \mu \mathrm{J})$ were used to vary the amount of $\mathrm{IP}_{3}$ released $(n=3)$ (Fig. $\left.2 \mathrm{~B}\right)$. Furthermore, intracellular application of heparin ( $1 \mathrm{mg} / \mathrm{ml}$; whole-cell dialysis), an $\mathrm{IP}_{3} \mathrm{R}$ antagonist (Ghosh et al., 1988), or bath application of cyclopiazonic acid (CPA) $(20 \mu \mathrm{M})$, which depletes intracellular $\mathrm{Ca}^{2+}$ stores (Seidler et al., 1989), completely abolished both $I_{\text {DHPG }}$ and $I_{\text {IP3 }}$ without affecting DHPG-induced delayed inward currents (Fig. 2C-F; recordings made with standard internal solution containing $25 \mu \mathrm{M}$
EGTA). CPA also eliminated DHPG- and muscarine-induced suppression of SPN firing ( $n=4$ and 3, respectively) (Fig. $2 G$ ).

We further made detailed analyses of $I_{\mathrm{IP} 3}$, since flash photolysis of caged $\mathrm{IP}_{3}$ enables much more quantitative and temporally precise application of $\mathrm{IP}_{3}$ compared with local pressure ejection of DHPG or muscarine. $I_{\mathrm{IP} 3}$ displayed concentrationdependent (i.e., UV flash intensitydependent) increases in total charge transfer (termed $Q_{\text {IP3 }}$ ) and half-width and a reduction in onset latency, accompanied by the emergence of an initial transient component with higher UV flash intensities $(100-200 \mu \mathrm{J})(n=5)$ (Fig. 3A-C). We next replaced EGTA in the internal solution with the same concentration $(25 \mu \mathrm{M})$ of BAPTA $(n=5)$. Although these two $\mathrm{Ca}^{2+}$ buffers have similar steady-state affinities for $\mathrm{Ca}^{2+}\left(K_{\mathrm{d}}=\sim 0.2 \mu \mathrm{M}\right)$, thus similarly affecting baseline $\left[\mathrm{Ca}^{2+}\right]_{\mathrm{i}}$, BAPTA is much more effective in disrupting transient localized $\mathrm{Ca}^{2+}$ signaling processes due to its faster $\mathrm{Ca}^{2+}$ binding rate ( $\sim 40-150$ times) compared with EGTA (Fakler and Adelman, 2008; Eggermann et al., 2011). BAPTA (25 $\mu \mathrm{M})$ reduced $Q_{\mathrm{IP} 3}$ and half-width of $I_{\mathrm{IP} 3}$ (measured at half the peak amplitude of the slow component) evoked by the highest UV intensity $(200 \mu \mathrm{J})$; however, it had no significant effect on the onset latency or the peak amplitudes of the initial or slow components. Increasing the BAPTA concentration to $1 \mathrm{mM}$ completely eliminated $I_{\text {IP3 }}(n=4)$, whereas measurable $I_{\text {IP3 }}$ was still observed with $1 \mathrm{~mm}$ EGTA $(n=4)$ (Fig. 3D). These data suggest that localized $\mathrm{Ca}^{2+}$ signaling is involved in the generation of $I_{\mathrm{IP} 3}$, presumably at the level of CICR among neighboring $\mathrm{IP}_{3} \mathrm{Rs}$ that acts to sustain $\mathrm{IP}_{3}$-induced $\mathrm{Ca}^{2+}$ rises.

When apamin and IbTX were tested on $I_{\text {IP3 }}(200 \mu \mathrm{J} \mathrm{UV}$ intensity), SK- and BKdependent components accounted for $78 \pm$ 7 and $22 \pm 7 \%$ of $Q_{\mathrm{IP} 3}$, respectively $(n=5$; three cells: apamin $\rightarrow$ IbTX + apamin; two cells: IbTX $\rightarrow$ apamin + IbTX) (Fig. 4A). The initial fast component was mostly BKmediated, suggesting that certain population of BK channels may have more direct access to $\mathrm{IP}_{3} \mathrm{R}$-mediated $\mathrm{Ca}^{2+}$ release. Small $\mathrm{IP}_{3}$-induced inward currents were observed in the presence of apamin and IbTX. These inward currents became larger with membrane hyperpolarization to $-87 \mathrm{mV}(12.9 \pm 1.6 \mathrm{pA}$ at $-57 \mathrm{mV}$ vs $26.4 \pm 2.0 \mathrm{pA}$ at $-87 \mathrm{mV}, n=7 ; t_{(6)}=7.60, p<0.001$, paired $t$ test), suggesting the involvement of a $\mathrm{Ca}^{2+}$-activated cationic conductance (Fleig and Penner, 2004). Stable $\mathrm{IP}_{3}$-induced currents were observed with repeated $\mathrm{IP}_{3}$ applications (once a minute) even when recorded cells were constantly held at -87 $\mathrm{mV}(n=5)$, indicating that $\mathrm{Ca}^{2+}$ stores can be replenished with- 

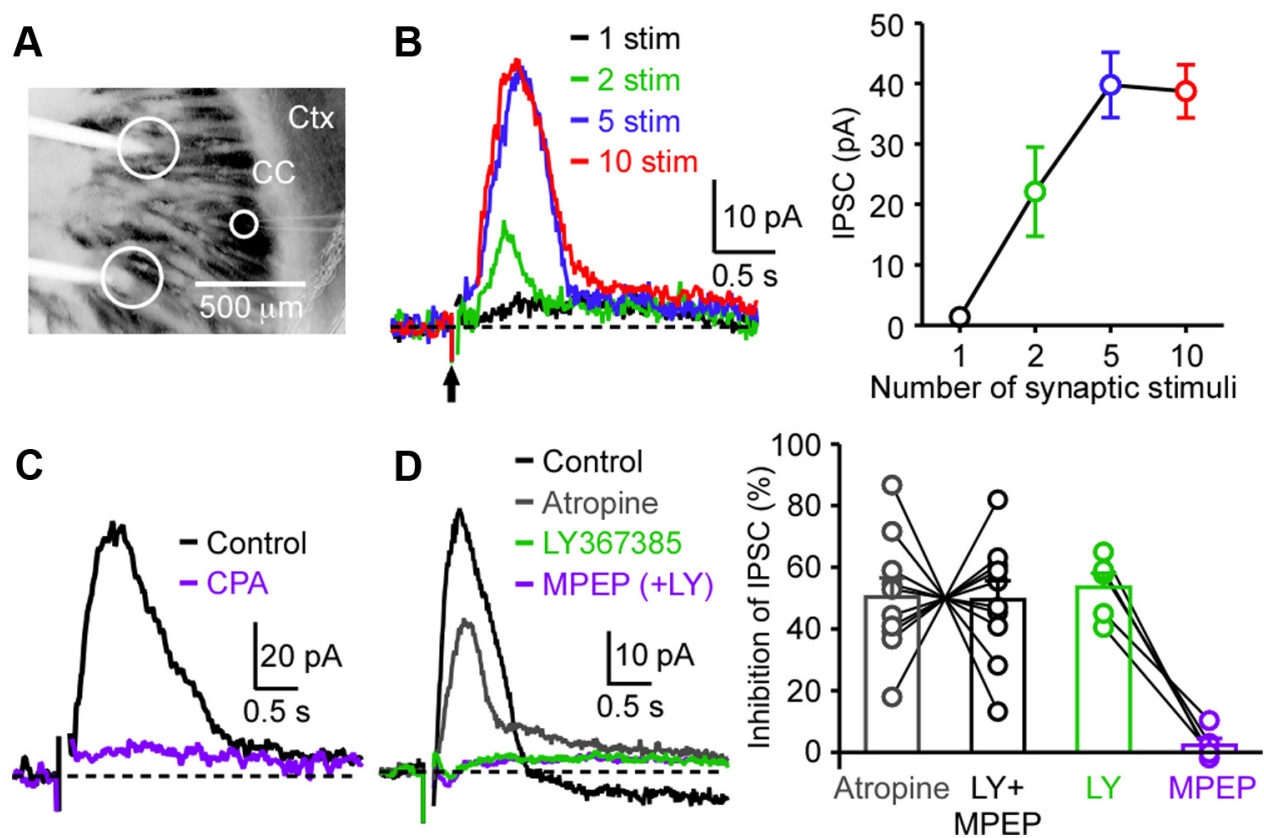

Figure 5. Intrastriatal stimulation elicits $\mathrm{Ca}^{2+}$ store-dependent $\mathrm{mGluR1/mAChR} \mathrm{IPSCS.} \mathrm{A,} \mathrm{Image} \mathrm{of} \mathrm{an} \mathrm{oblique} \mathrm{horizontal} \mathrm{striatal} \mathrm{slice} \mathrm{depicting} \mathrm{the} \mathrm{placement} \mathrm{of} \mathrm{a} \mathrm{bipolar} \mathrm{stimulating} \mathrm{electrode} \mathrm{(tips} \mathrm{inside}$ large circles) with respect to the recorded cell (inside the small circle). Ctx, Cortex; $C$ C, corpus callosum. B, Example traces illustrating synaptic responses produced by trains of 1-10 intrastriatal stimuli ( $50 \mathrm{~Hz}$ ). The arrow indicates the onset of stimulus trains. Stimulus artifacts are omitted from these traces for clarity. Right, Summary graph plotting the IPSC amplitude evoked by trains of 1-10 stimuli in four cells. $C$, Representative traces showing the effect of (PA $(20 \mu \mathrm{M})$. D, Example traces and summary graph showing the effects of atropine $(2 \mu \mathrm{M})$, LY367385 (75 nM), and MPEP (50 nM) on IPSCS. Percentage inhibition was calculated after removing the current insensitive to the combined application of these antagonists in each cell. Of 10 cells examined for all three antagonists, LY367385 and MPEP were applied together at the same time in 5 cells and sequentially in the remaining 5 cells. The order of drug application was varied in these experiments. Error bars indicate SEM.

out VGCC-mediated $\mathrm{Ca}^{2+}$ influx (i.e., priming) in SPNs (Hong and Ross, 2007; Wu et al., 2011).

In current clamp, photolytic $\mathrm{IP}_{3}$ application produced a pause in SPN firing $(0.68 \pm 0.03 \mathrm{~s} ; n=9)$. Apamin and IbTX reduced the duration of this $\mathrm{IP}_{3}$-induced pause by $47 \pm 5 \%(n=4)$ and $22 \pm 9 \%$ $(n=5)$, respectively, while combined application of apamin and IbTX eliminated the pause $(n=3)$ (Fig. $4 B-D) . \mathrm{IP}_{3}$ application produced small depolarizations at the resting membrane potential $(1.8 \pm 0.1$ $\mathrm{mV} ; n=10$ ), consistent with the cationic conductance described above.

Together, these data indicate that $\mathrm{IP}_{3} \mathrm{R}$-mediated $\mathrm{Ca}^{2+}$ release from intracellular stores, causing activation of SK and $\mathrm{BK}$ channels, is responsible for mGluR- and mAChR-induced inhibition of SPNs.

Synaptic stimulation triggers mGluRand $\mathrm{mAChR}$-mediated IPSCs

We next examined synaptic responses (AMPA, NMDA, and $\mathrm{GABA}_{\mathrm{A}}$ receptors blocked) elicited by intrastriatal stimulation using a bipolar stimulating electrode $(\sim 600 \mu \mathrm{m}$ tip separation) placed caudal to the recorded cell $(\sim 500-600 \mu \mathrm{m}$ away) (Fig. 5A). This likely causes stimulation of a large number of inputs arising from all available sources, both intrinsic fibers from striatal neurons and extrinsic inputs from other structures, including those from the cortex via antidromic stimulation
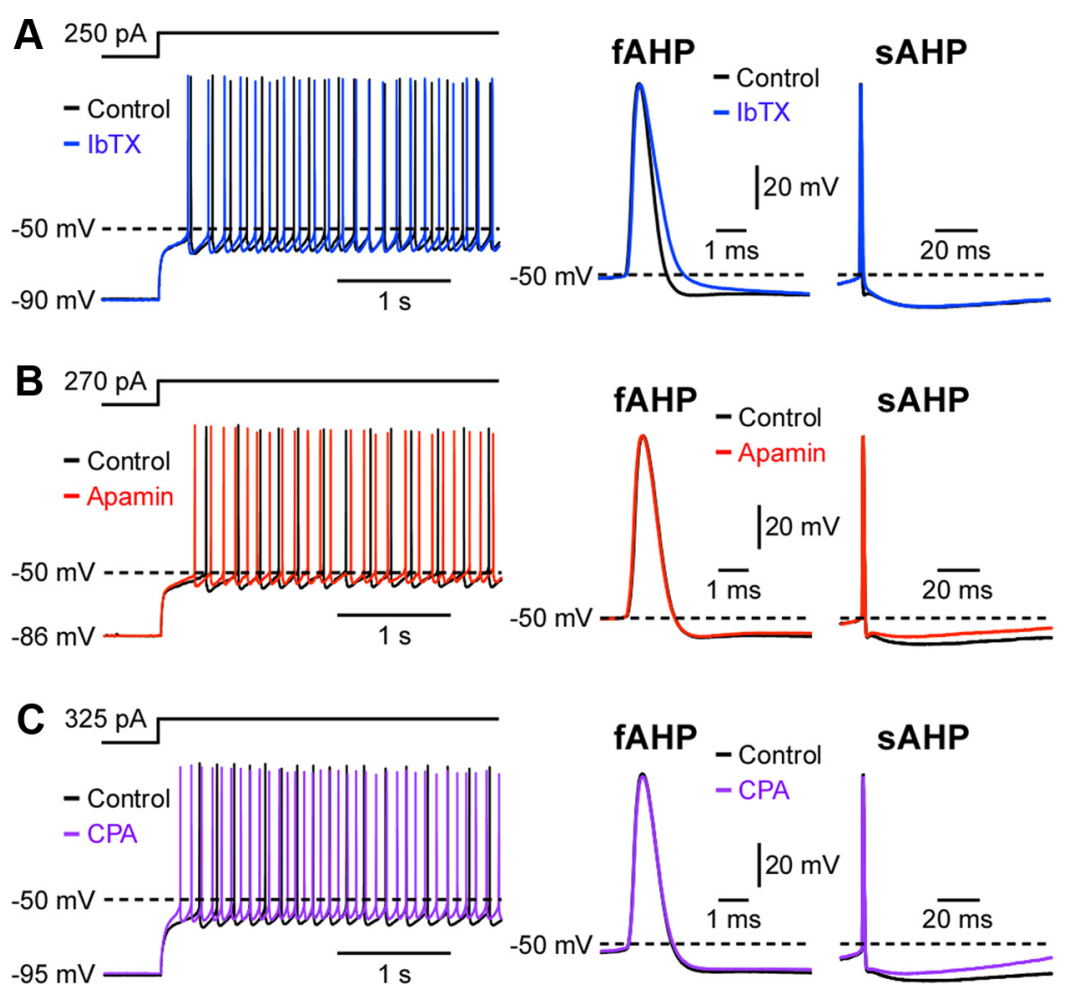

Figure 6. $\mathrm{Ca}^{2+}$ release from intracellular stores regulates SK-dependent slow AHPs. Example traces showing the effects of IbTX (100 $\mathrm{nm} ; \boldsymbol{A})$, apamin (100 nм; $\boldsymbol{B})$, and CPA (20 $\mu \mathrm{m} ; \boldsymbol{C})$ on SPN firing. Right, First APs evoked by depolarizing current injections are shown on expanded timescales, with the AP onset aligned, to illustrate the effects of these drugs on the AP shape and two AHP components.
(Cowan and Wilson, 1994). Although single stimuli (500 $\mu$ s; $\sim 1-2 \mathrm{~mA}$ ) failed to produce measurable responses, trains of $2-10$ stimuli at $50 \mathrm{~Hz}$ evoked slow IPSC-like outward currents $\left(V_{\mathrm{h}}=\right.$ $-57 \mathrm{mV}$ ) (Fig. 5B). A train of 5 stimuli produced a near- 
Table 1. Effects of IbTX, apamin, and CPA on electrophysiological properties of SPNs

\begin{tabular}{|c|c|c|c|c|c|c|c|c|}
\hline & \multicolumn{2}{|l|}{$\operatorname{IbTX}(n=6)$} & \multicolumn{2}{|l|}{$\operatorname{Apamin}(n=6)$} & \multicolumn{2}{|l|}{ CPA $(n=8)$} & \multicolumn{2}{|c|}{ CPA in apamin $(n=4)$} \\
\hline & Control & IbTX & Control & Apamin & Control & CPA & Apamin & CPA \\
\hline AP threshold (mV) & $-46.6 \pm 1.5$ & $-46.8 \pm 1.7$ & $-47.6 \pm 1.4$ & $-48.2 \pm 1.5$ & $-47.3 \pm 1.6$ & $-47.7 \pm 1.6$ & $-48.2 \pm 1.2$ & $-49.5 \pm 1.1$ \\
\hline AP half-width (ms) & $0.80 \pm 0.02$ & $1.05 \pm 0.05^{* *}$ & $0.72 \pm 0.02$ & $0.73 \pm 0.02$ & $0.75 \pm 0.02$ & $0.76 \pm 0.02$ & $0.74 \pm 0.02$ & $0.75 \pm 0.02$ \\
\hline AP decay rate (ms) & $0.38 \pm 0.02$ & $0.59 \pm 0.03^{* *}$ & $0.33 \pm 0.01$ & $0.33 \pm 0.01$ & $0.35 \pm 0.01$ & $0.36 \pm 0.01$ & $0.34 \pm 0.01$ & $0.34 \pm 0.00$ \\
\hline Latency to first AP (ms) & $567 \pm 34$ & $510 \pm 23$ & $560 \pm 25$ & $410 \pm 21^{* *}$ & $551 \pm 37$ & $401 \pm 51^{* *}$ & $437 \pm 17$ & $458 \pm 22$ \\
\hline Interspike interval (ms) & $175 \pm 6$ & $174 \pm 10$ & $171 \pm 8$ & $101 \pm 2^{* * *}$ & $159 \pm 7$ & $116 \pm 11^{* *}$ & $104 \pm 1$ & $108 \pm 5$ \\
\hline fAHP amplitude (mV) & $9.7 \pm 0.6$ & $4.0 \pm 0.8^{* * *}$ & $10.2 \pm 1.1$ & $9.8 \pm 1.1$ & $11.5 \pm 0.4$ & $10.9 \pm 0.4$ & $11.1 \pm 1.0$ & $11.1 \pm 1.1$ \\
\hline sAHP amplitude (mV) & $14.5 \pm 0.5$ & $14.2 \pm 0.4$ & $14.5 \pm 0.4$ & $11.3 \pm 0.6^{* * *}$ & $14.4 \pm 0.5$ & $12.9 \pm 0.4^{* *}$ & $12.0 \pm 0.3$ & $11.9 \pm 0.4$ \\
\hline $\operatorname{RMP}(\mathrm{mV})$ & $-87.1 \pm 1.6$ & $-87.6 \pm 1.3$ & $-89.8 \pm 1.1$ & $-90.7 \pm 1.3$ & $-89.4 \pm 1.7$ & $-90.1 \pm 2.0$ & $-91.3 \pm 0.9$ & $-91.8 \pm 1.0$ \\
\hline Input resistance $(M \Omega)$ & $61.0 \pm 9.6$ & $65.6 \pm 11.1$ & $53.2 \pm 5.2$ & $54.5 \pm 5.4$ & $56.1 \pm 5.7$ & $56.8 \pm 5.5$ & $53.3 \pm 8.4$ & $53.6 \pm 8.5$ \\
\hline
\end{tabular}

${ }^{*} p<0.05 ;{ }^{* *} p<0.01 ;{ }^{* * *} p<0.001$ (paired $t$ test).
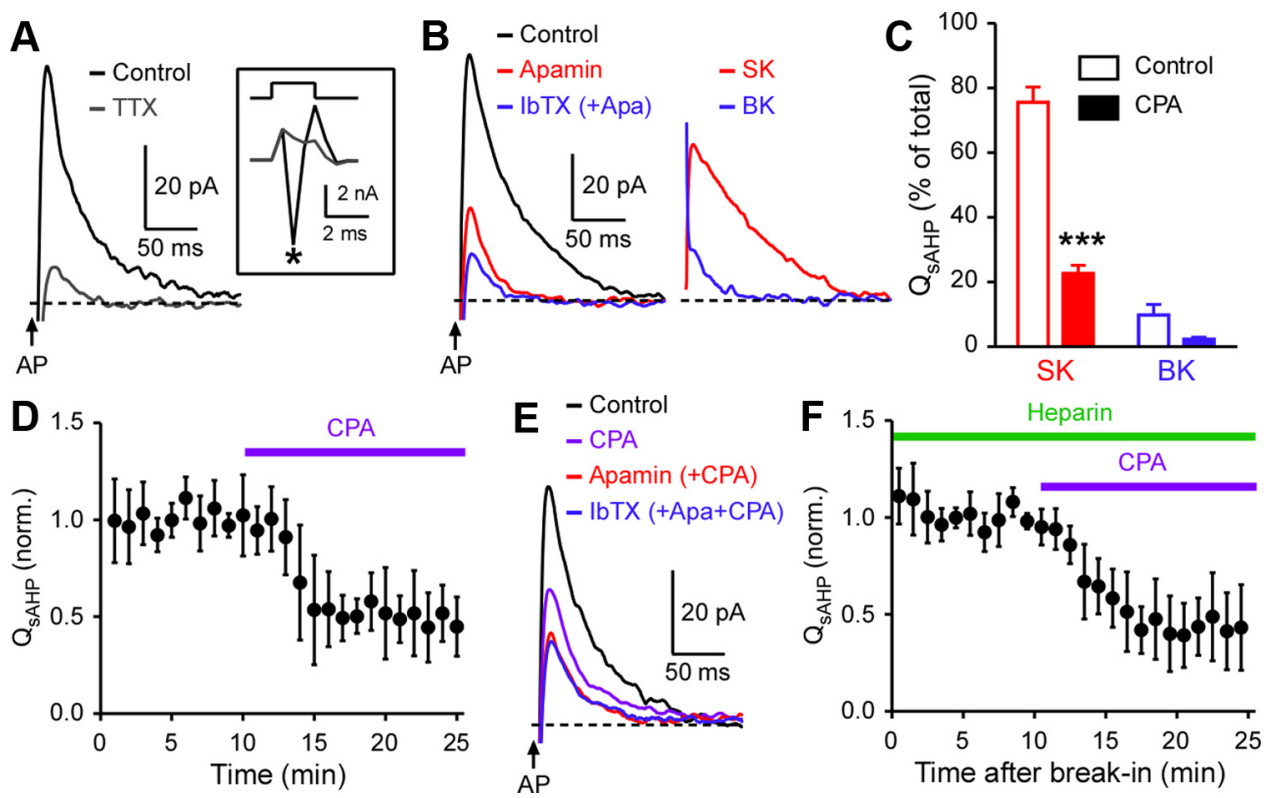

Figure 7. $\mathrm{Ca}^{2+}$ store-dependent regulation of slow AHP currents is not dependent on $\mathrm{IP}_{3} \mathrm{Rs} . A$, Example traces showing that TTX (1 mM) largely suppressed $I_{\text {sAHP. }}$. Inset, Traces of currents during the $2 \mathrm{~ms}$ depolarization are shown on an expanded scale ( $2 \mathrm{~Hz}$ sampling frequency). Note that TTX abolished the inward action current (asterisk). $\boldsymbol{B}$, Example traces depicting the effects of apamin $(100 \mathrm{nM})$ and IbTX (100 nM) on I $I_{\text {sAHP }}$ elicited by unclamped APs. Currents during unclamped APs (at the time indicated by the arrow) are omitted for clarity. Traces of SK- and BK-dependent components of $I_{\text {sAHP }}$ are shown on the right. The small apamin/lbTX-insensitive component likely reflects activation of voltage-gated $\mathrm{K}^{+}$conductance. C, Summary bar graph showing the fraction of $Q_{\text {SAHP }}$ carried by SK- and BK-dependent components in control solution and after application of CPA $(20 \mu \mathrm{M})$. Note that the data in CPA represent percentage of total $Q_{\text {SAHP }}$ before $C P A$ application in each cell [external solution (control vs (PA): $F_{(1,14)}=77.7, p<0.0001$; current type (SK vs BK): $F_{(1,14)}=158, p<0.0001$; external solution by current type: $F_{(1,14)}=43.9, p<0.0001$; two-way ANOVA]. ${ }^{* * *} p<0.001$ versus control solution (Bonferroni's post hoc test). $\boldsymbol{D}$, Summary time graph illustrating (PA-induced suppression of $Q_{\text {sAHP. }}$, Example traces of $I_{\text {sAHP }}$ depicting the effects of CPA, apamin, and IbTX applied sequentially. $\boldsymbol{F}$, Summary time graph demonstrating that heparin failed to affect CPA-induced suppression of $Q_{\text {sAHP. }}$. Error bars indicate SEM.

saturating response in four cells tested for various train lengths (1-10 stimuli), and hence were used in the following experiments. IPSC-like outward currents thus evoked, which peaked at $0.47 \pm$ $0.03 \mathrm{~s}$ after the onset of stimulus train and had a half-width of $0.58 \pm$ $0.03 \mathrm{~s}(n=14)$, were largely suppressed by CPA $(20 \mu \mathrm{M} ; n=4)$ and also by combined application of LY367385 (mGluR1 antagonist; 75 $\mathrm{nM})$, MPEP (mGluR5 antagonist; $50 \mathrm{nM}$ ), and atropine (mAChR antagonist; $2 \mu \mathrm{M})(n=10)$ (Fig. $5 C, D)$, indicating that they mostly represent $\mathrm{Ca}^{2+}$ store-dependent mGluR/mAChR IPSCs. Small outward currents ( $\sim 10 \mathrm{pA}$ or less) routinely remained after application of CPA or the mGluR/mAChR antagonist mixture. The outward currents in the presence of antagonist mixture were not suppressed by subsequent application of $\mathrm{CPA}(n=3)$ or the $\mathrm{GABA}_{\mathrm{B}}$ receptor antagonist CGP54626 ( $1 \mu \mathrm{M} ; n=3)$, and thus their identity is currently unknown. On average, mGluR- and mAChR-mediated components made equal contributions to IPSCs, while mGluR1 accounted for the vast majority of the mGluR-dependent component. All 10 cells examined had both mGluR-and mAChR-mediated components, although the relative size varied from cell to cell. These results demonstrate that synaptic stimulation of glutamatergic and cholinergic inputs produces $\mathrm{Ca}^{2+}$ store-dependent inhibition of SPNs. Delayed EPSCs $(\sim 10 \mathrm{pA})$ sensitive to atropine were observed in 3 of 14 cells.

\section{RyR-dependent, but $\mathrm{IP}_{3} \mathrm{R}$-independent, $\mathrm{Ca}^{2+}$ release contributes to slow AHPs}

It has been shown that AP-evoked $\mathrm{Ca}^{2+}$ influx activates $\mathrm{BK}$ and SK channels, thereby producing fast and slow AHPs (fAHPs and sAHPs) in SPNs (Pineda et al., 1992; Hopf et al., 2010). In line with these studies, IbTX increased the AP half-width and suppressed fAHPs (peaked at $\sim 2-3 \mathrm{~ms}$ after AP onset) without affecting the interspike interval $(n=6)$, indicating the role of BK channels in AP repolarization, whereas apamin depressed sAHPs (peaked at $\sim 20-40 \mathrm{~ms}$ after AP onset) and decreased the interspike interval $(n=6)$ (Fig. $6 A, B$; Table 1$)$. CICR from intracellular stores triggered by AP-evoked $\mathrm{Ca}^{2+}$ influx may contribute to sAHPs (Berridge, 1998). We found that $\mathrm{Ca}^{2+}$ store depletion with CPA dramatically suppressed sAHPs and decreased the in- 
terspike interval $(n=8)$, an effect that was occluded by previous application of apamin $(n=4)$ (Fig. $6 C$, Table 1$)$. Therefore, CICR contributes to SK-dependent sAHPs in SPNs. Apamin and CPA also accelerated the initial ramp-like depolarizations preceding the first AP during depolarizing current injections, demonstrating that CICR-dependent SK channel activation, in addition to activation of voltage-gated $\mathrm{K}^{+}$conductances (Nisenbaum and Wilson, 1995), is capable of delaying the firing response to depolarizing inputs.

We next measured the currents underlying sAHPs in voltage clamp, as has been done previously in midbrain dopamine neurons and striatal cholinergic interneurons (Goldberg and Wilson, 2005; Cui et al., 2007). Here, 2 ms depolarizing pulses to $-7 \mathrm{mV}$ from a holding potential of $-57 \mathrm{mV}$ were applied to evoke unclamped APs, which resulted in tail outward currents $\left(I_{\mathrm{sAHP}}\right)$ lasting $\sim 200 \mathrm{~ms}$ (Fig. $7 A$ ). We calculated the time integral of $I_{\text {sAHP }}$ (i.e., the total charge transfer) after removing a $10 \mathrm{~ms}$ window following the $2 \mathrm{~ms}$ depolarizing pulse. $Q_{\mathrm{sAHP}}$ thus obtained was largely suppressed (87 \pm $2 \% ; n=4)$ by TTX $(1 \mu \mathrm{M})$, consistent with the role of unclamped APs in generating $I_{\mathrm{sAHP}}$. Apamin and IbTX reduced $Q_{\text {sAHP }}$ by $76 \pm 5$ and $10 \pm 3 \%$, respectively $(n=5$; three cells: apamin $\rightarrow$ IbTX + apamin; two cells: IbTX $\rightarrow$ apamin + IbTX) (Fig. $7 B, C$ ). $\mathrm{Ca}^{2+}$ store depletion with CPA depressed $Q_{\mathrm{AHP}}$ by $56 \pm 7 \%$ $(n=5)$ (Fig. $7 D, E)$. Furthermore, prior application of CPA dramatically reduced the SK-dependent component of $Q_{\mathrm{sAHP}}$ and eliminated the small BK-dependent component $(n=4)$ (Fig. 7C,E). Thus, CICR-dependent activation of SK channels largely mediates $I_{\mathrm{sAHP}}$ evoked by unclamped APs, consistent with its dominant role in controlling sAHPs and interspike interval during depolarizationinduced firing described above (Fig. 6, Table 1).

AP-induced CICR that mediates sAHPs frequently occurs via RyRs (Sah and McLachlan, 1991; Kakizawa et al., 2007), although $\mathrm{IP}_{3}$ Rs may also play a role (Cui et al., 2007). We next recorded $I_{\text {sAHP }}$ with heparin $(1 \mathrm{mg} / \mathrm{ml})$ in the recording pipette to test the involvement of $\mathrm{IP}_{3} \mathrm{Rs}$. Heparin, which abolished $I_{\mathrm{DHPG}}$ and $I_{\mathrm{IP} 3}$ in $\sim 5$ min (Fig. $2 C, D$ ), had no effect on $Q_{\mathrm{sAHP}}(n=5)$ (Fig. $\left.7 F\right)$. Furthermore, it failed to suppress CPA-induced depression of $Q_{\mathrm{sAHP}}(55 \pm 8 \%, n=5 ; p=$ 0.94 vs CPA effect with control internal solution, unpaired $t$ test). Therefore, IP ${ }_{3} \mathrm{Rs}$ are not involved in the CICR-dependent component of sAHPs.

To examine the involvement of RyRs, we used caffeine, which increases the $\mathrm{Ca}^{2+}$ sensitivity of RyRs while at the same time blocks $I_{3}{ }_{3}$ Rs (Ehrlich et al., 1994). Bath application of caffeine (1
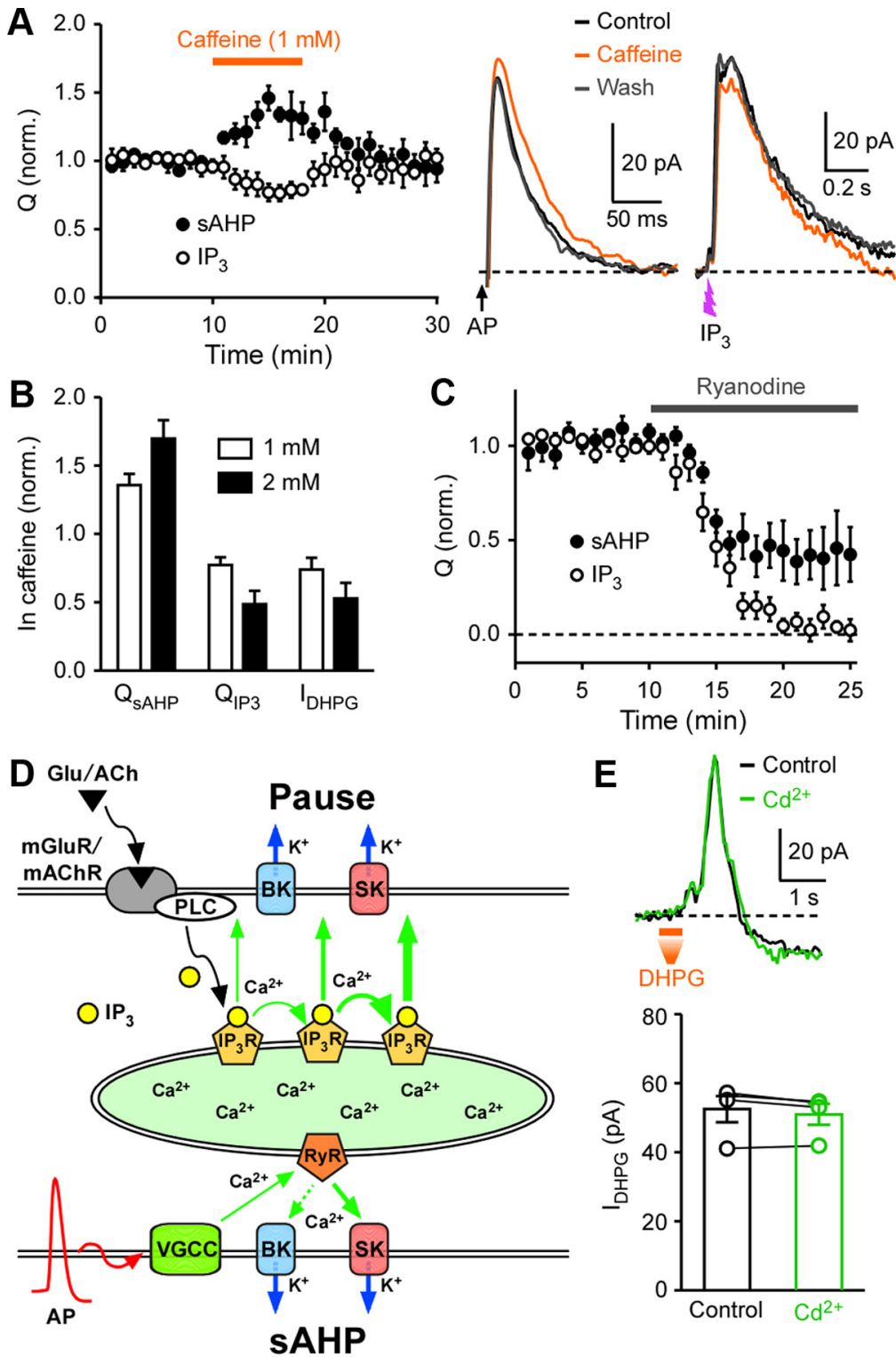

Figure 8. Functional segregation of $\mathrm{IP}_{3} R s$ and RyRs. $A$, Summary time graph illustrating the effects of caffeine $(1 \mathrm{~mm})$ on $Q_{s A H P}$

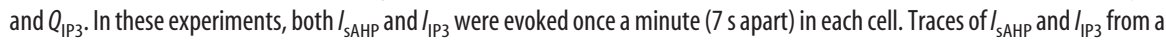
sample experiment are shown on the right. $B$, Summary bar graph showing the effects of caffeine ( 1 and $2 \mathrm{mM}$ ) on $Q_{S_{A A P},} Q_{1 P 3}$, and $I_{\text {DHPG }}$. C, Summary time graph depicting ryanodine $(20 \mu \mathrm{M})$-induced depression of $Q_{S A H P}$ and $Q_{\mid P 3}$. D, Schematic diagram illustrating the functional segregation two $\mathrm{Ca}^{2+}$ signaling pathways mediating $\mathrm{Ca}^{2+}$ store-dependent activation of SK and BK channels: (1) $\mathrm{mGluR} / \mathrm{mAChR} \rightarrow \mathbb{P}_{3} \rightarrow \mathbb{P}_{3}$ R pathway and (2) AP $\rightarrow \mathrm{VGCC} \rightarrow$ RyR pathway. This diagram does not include the direct coupling between VGCC-mediated $\mathrm{Ca}^{2+}$ influx and SK/BK channels (Fakler and Adelman, 2008). E, Representative traces (top) and summary graph (bottom) showing that $\mathrm{Cd}^{2+}(100 \mu \mathrm{M})$ had no significant effect on $I_{\mathrm{DHPG}}$. Error bars indicate SEM.

and $2 \mathrm{mM}$ ) reversibly increased $Q_{\mathrm{sAHP}}$ but depressed $I_{\mathrm{IP} 3}$ and $I_{\text {DHPG }}$ in a concentration-dependent manner (Fig. $8 \mathrm{~A}, \mathrm{~B}$ ). We further tested the effect of ryanodine $(20 \mu \mathrm{M})$, which locks RyR channels in a subconductance open state and thus depletes $\mathrm{Ca}^{2+}$ stores expressing RyRs (Zucchi and Ronca-Testoni, 1997). Ryanodine inhibited $Q_{\mathrm{sAHP}}$ by $56 \pm 8 \%(n=5)$, an inhibition virtually identical with that produced by $\mathrm{CPA}$, and completely abolished $I_{\mathrm{IP} 3}$ (Fig. $8 C$ ). These data demonstrate that, although $\mathrm{IP}_{3} \mathrm{Rs}$ and RyRs are coexpressed on the same $\mathrm{Ca}^{2+}$ stores, these two $\mathrm{Ca}^{2+}$ release channels are functionally segregated, where $\mathrm{IP}_{3}$ selectively elicits $\mathrm{IP}_{3} \mathrm{R}$-mediated $\mathrm{Ca}^{2+}$ release, without invoking $\mathrm{CICR}$ via RyRs, to mediate mGluR/mAChR-induced inhibition of SPN activity, whereas AP-induced $\mathrm{Ca}^{2+}$ influx through VGCCs selec- 

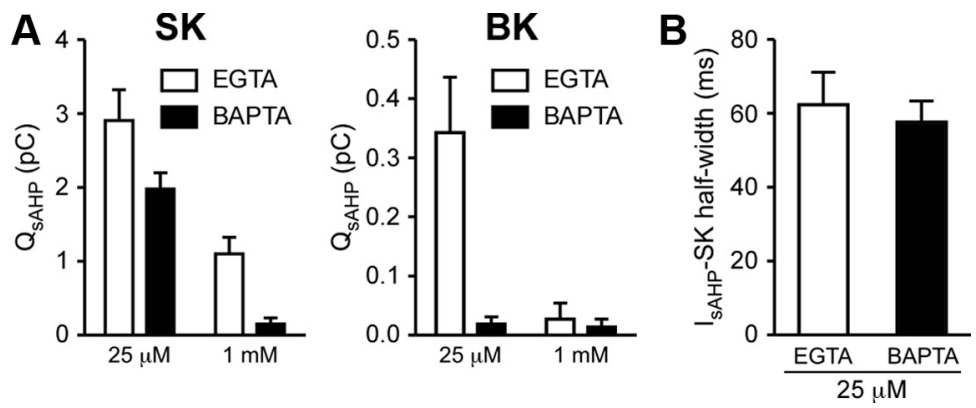

Figure 9. BAPTA-sensitive localized $\mathrm{Ca}^{2+}$ signaling is involved in the generation of $I_{\text {sAHP. }} \boldsymbol{A}$, Summary bar graphs plotting SKand BK-dependent components of $Q_{\text {SAHP }}$ in cells filled with two different concentrations ( $25 \mu \mathrm{m}$ and $1 \mathrm{~mm}$ ) of EGTA or BAPTA (SK-dependent component: $\mathrm{Ca}^{2+}$ buffer type, $F_{(1,11)}=7.90, p<0.05 ; \mathrm{Ca}^{2+}$ buffer concentration, $F_{(1,11)}=29.7, p<0.001$; BK-dependent component: $\mathrm{Ca}^{2+}$ buffertype, $F_{(1,11)}=6.08, p<0.05 ; \mathrm{Ca}^{2+}$ buffer concentration, $F_{(1,11)}=5.50, p<0.05, \mathrm{Ca}^{2+}$ buffer type by concentration, $F_{(1,11)}=5.15, p<0.05$; two-way ANOVA). $B$, Summary bar graph showing that BAPTA $(25 \mu \mathrm{m})$ did not affect the half-width of the SK-dependent component of $I_{\text {SAHP }}\left(t_{(7)}=0.43, p=0.68\right.$; unpaired $t$ test $)$. Error bars indicate SEM.

tively recruits RyR-mediated $\mathrm{Ca}^{2+}$ release to generate sAHPs (Fig. $8 D$ ). $\mathrm{Ca}^{2+}$ influx through certain types of VGCCs at depolarized potentials may enlarge the size of $\mathrm{Ca}^{2+}$ stores (Power and Sah, 2005) or enhance the activity of PLC (Nevian and Sakmann, 2006); however, we found that bath application of the general VGCC blocker $\mathrm{Cd}^{2+}(100 \mu \mathrm{M})$, which suppressed $Q_{\text {sAHP }}$ by $78 \pm$ $1 \%(n=3)$, had no significant effect on $I_{\text {DHPG }}$ measured at -57 $\mathrm{mV}(n=4)$ (Fig. $8 E$ ), further confirming that $\mathrm{Ca}^{2+}$ stores can be maintained without VGCC-mediated $\mathrm{Ca}^{2+}$ influx in SPNs.

We next tested EGTA/BAPTA sensitivity of SK- and BKdependent components of $I_{\text {sAHP }}\left(I_{\text {sAHP }}-S K\right.$ and $\left.I_{\text {sAHP }}-B K\right)$ (Fig. 9). Replacing $25 \mu \mathrm{M}$ EGTA with $25 \mu \mathrm{M}$ BAPTA depressed $I_{\text {sAHP }^{-}}$ SK, without changing its half-width, and abolished $I_{\mathrm{sAHP}}-\mathrm{BK}$. Increasing the BAPTA concentration to $1 \mathrm{~mm}$ virtually eliminated $I_{\mathrm{sAHP}}-\mathrm{SK}$, while measurable $I_{\mathrm{sAHP}}-\mathrm{SK}$ was observed with 1 mM EGTA, although reduced in size compared with that in $25 \mu \mathrm{M}$ EGTA. Thus, both components were more sensitive to BAPTA than to EGTA, implying the involvement of localized $\mathrm{Ca}^{2+}$ signaling processes. The higher sensitivity of $I_{\mathrm{sAHP}}-\mathrm{BK}$ to these $\mathrm{Ca}^{2+}$ buffers compared with $I_{\text {sAHP }}$-SK likely reflects different $\mathrm{Ca}^{2+}$ sensitivity of BK versus SK channels.

\section{$\mathrm{IP}_{3}$-induced $\mathrm{Ca}^{2+}$ signaling is absent in striatal interneurons} A previous immunohistochemical study has shown that expression of neuronal type $1 \mathrm{IP}_{3} \mathrm{Rs}$ is restricted to SPNs in the striatum, with little or no $\mathrm{IP}_{3} \mathrm{R}$ expression in other aspiny neurons, particularly in cholinergic neurons and parvalbumin-containing neurons, whereas RyRs are expressed in virtually all striatal neurons (Martone et al., 1997). In agreement with this study, flash photolysis of caged $\mathrm{IP}_{3}(400 \mu \mathrm{M} ; \sim 200 \mu \mathrm{J} \mathrm{UV}$ intensity), as well as trains of 5-10 unclamped APs at $20 \mathrm{~Hz}$, invariably produced robust $\mathrm{Ca}^{2+}$ transients in all SPNs tested [nine cells with $100 \mu \mathrm{M}$ Fluo-4FF $\left(K_{\mathrm{d}}=9.7 \mu \mathrm{M}\right)$, two cells with $100 \mu \mathrm{M}$ Fluo-5F $\left(K_{\mathrm{d}}=2.3\right.$ $\mu \mathrm{M})$, one cell with $200 \mu \mathrm{M}$ Fluo-4 $\left.\left(K_{\mathrm{d}}=0.35 \mu \mathrm{M}\right)\right]$ (Fig. $\left.10 A\right)$. In contrast, the same photolytic application of $\mathrm{IP}_{3}$ failed to evoke detectable $\mathrm{Ca}^{2+}$ rises in electrophysiologically identified cholinergic interneurons (ChIs) $(n=4)$, fast-spiking interneurons (FSIs) $(n=3)$, and low-threshold spike (LTS) interneurons $(n=$ 3 ) even when $\left[\mathrm{Ca}^{2+}\right]_{\mathrm{i}}$ was monitored with the high-affinity indicator Fluo-4 $(200 \mu \mathrm{M})$, while trains of unclamped APs (ChIs and LTS neurons: 5 APs at $10 \mathrm{~Hz}$; FSIs: 5-10 APs at $20 \mathrm{~Hz}$ ) were capable of producing $\mathrm{Ca}^{2+}$ transients (Fig. $10 B-D$ ). When recordings were made with our routine internal solution containing $25 \mu \mathrm{M}$ EGTA (without $\mathrm{Ca}^{2+}$ indicators), $\mathrm{IP}_{3}$ application elicited no measurable currents, while unclamped APs evoked apamin-sensitive $I_{\text {sAHP }}$, in ChIs $(n=4)$ and LTS neurons $\left(n=3 ; \mathrm{IP}_{3}\right.$ tested in two of these three cells) (Fig. $10 \mathrm{E}$ ). No $\mathrm{IP}_{3}$ evoked currents or $I_{\text {sAHP }}$ were observed in FSIs $(n=5)$ (data not shown). These data strongly suggest that functional $\mathrm{IP}_{3} \mathrm{Rs}$ are selectively expressed in SPNs among different types of striatal neurons.

\section{Discussion}

Inhibitory regulation of SPN activity is thought to be achieved either through feedback inhibition among SPNs or via feedforward inhibition by GABAergic interneurons, recruited by extrinsic glutamatergic and local cholinergic inputs (Ponzi and Wickens, 2010; English et al., 2012; Gittis and Kreitzer, 2012). Here, we found that glutamatergic and cholinergic inputs can directly inhibit SPNs via $\mathrm{mGluR} / \mathrm{mAChR}$-induced intracellular $\mathrm{Ca}^{2+}$ release and subsequent activation of SK and BK channels. $\mathrm{IP}_{3}$ Rs are selectively involved in $\mathrm{mGluR} / \mathrm{mAChR}$ induced $\mathrm{Ca}^{2+}$ release without playing a role in CICR triggered by $\mathrm{AP}$-evoked $\mathrm{Ca}^{2+}$ influx. Intriguingly, $\mathrm{IP}_{3}$-induced $\mathrm{Ca}^{2+}$ release is not observed in striatal interneurons. Therefore, $\mathrm{IP}_{3}$ signaling is uniquely involved in glutamatergic and cholinergic inhibition of striatal output neuron activity.

\section{Mechanisms of mGluR- and mAChR-induced inhibition}

Both local pressure ejection of agonists and intrastriatal stimulation of glutamatergic and cholinergic inputs produce $\mathrm{Ca}^{2+}$ storedependent inhibitory responses in SPNs. Experiments were mostly performed in the presence of the $\mathrm{GABA}_{\mathrm{A}}$ blocker picrotoxin, ruling out the contribution of local GABAergic network. Curiously, the mGluR-dependent component of IPSCs is almost exclusively mediated by the mGluR1 subtype, while pressure ejection of DHPG, which would reach an area surrounding the soma, proximal dendrites, and maybe part of more distal dendrites equipped with spines, equally engages both mGluR 1 and mGluR5. Previous ultrastructural studies in SPNs have shown that both mGluR1 and mGluR5 are equally distributed on dendritic spines and shafts, mostly at extrasynaptic sites, although mGluR5 is more frequently detected than mGluR1 at the soma (Paquet and Smith, 2003; Mitrano and Smith, 2007). Pharmacologically, these two mGluR subtypes have similar affinities to glutamate as well as to DHPG (Schoepp et al., 1999). Therefore, it is not clear why mGluR5-dependent IPSCs were not detected. Of note, distinct roles of mGluR1 versus mGluR5 on AMPA/ NMDA-mediated glutamatergic transmission and plasticity have been reported in SPNs (Gubellini et al., 2004). It remains to be determined how these two mGluR subtypes differentially sense synaptically released glutamate and signal its consequence.

$\mathrm{mAChR}$-dependent inhibitory responses are most likely mediated by the PLC-coupled $M_{1}$ subtype, which is expressed in virtually all SPNs (Yan et al., 2001). The majority of cholinergic terminals in the striatum, which arise from ChIs, do not make synaptic contacts onto other neurons (Contant et al., 1996). This, together with the extrasynaptic localization of mGluRs described above, may account for the requirement of repetitive, highfrequency stimulation to elicit IPSCs via extrasynaptic diffusion of glutamate/ACh (Brasnjo and Otis, 2001). mAChR-dependent inhibition may contribute, in part, to the suppression of SPN 
firing caused by selective excitation of ChIs in vivo (Witten et al., 2010; English et al., 2012).

SK channels and, to a smaller degree, BK channels both contribute to mGluRand $\mathrm{IP}_{3}$-induced outward currents. mGluR/ $\mathrm{mAChR} / \mathrm{IP}_{3}$-induced outward currents/ hyperpolarizations are entirely mediated by SK channels in cortical pyramidal neurons (Gulledge and Stuart, 2005; Hagenston et al., 2008), hippocampal CA1 pyramidal neurons (El-Hassar et al., 2011), basolateral amygdala (BLA) neurons (Power and Sah, 2008), and midbrain dopamine neurons (Fiorillo and Williams, 2000; Morikawa et al., 2000, 2003). In contrast, $\mathrm{mGluR} / \mathrm{IP}_{3}$-induced $\mathrm{Ca}^{2+}$ signaling is exclusively coupled to BK channels in cerebellar Purkinje neurons (Khodakhah and Ogden, 1995; Canepari and Ogden, 2006), even though these neurons express SK channels (Womack and Khodakhah, 2003). SK channels are solely gated by $\mathrm{Ca}^{2+}$ with submicromolar affinity, while BK channels are gated by voltage and $\mathrm{Ca}^{2+}$ (Fakler and Adelman, 2008). Both strong depolarization $(\geq 0 \mathrm{mV})$ and very high $\left[\mathrm{Ca}^{2+}\right]_{\mathrm{i}}$ $(\geq 10 \mu \mathrm{M})$ are generally necessary to activate $\mathrm{BK}$ channels. This large difference in $\mathrm{Ca}^{2+}$ sensitivity readily accounts for the major contribution of SK channels at rather hyperpolarized potentials (below $-50 \mathrm{mV}$ ) in many neurons described above. However, recent evidence indicates that $\mathrm{BK}$ channel gating is dramatically enhanced by auxiliary proteins, termed LRRC (leucine-rich repeat-containing) proteins, which allow BK channel activation by submicromolar to micromolar $\left[\mathrm{Ca}^{2+}\right]_{\mathrm{i}}$ even at hyperpolarized potentials (Yan and Aldrich, 2010, 2012). mRNAs of these proteins are found in the brain, raising the possibility that certain BK channels might have high $\mathrm{Ca}^{2+}$ sensitivity in neurons. Indeed, BK- and SK-dependent components of $I_{\mathrm{DHPG}}$ and $I_{\mathrm{IP} 3}$ had similar kinetics (except for the initial BK component of $I_{\mathrm{IP} 3}$ ), suggesting that these two $\mathrm{Ca}^{2+}$-activated channels may be sensing the same $\mathrm{Ca}^{2+}$ signals in SPNs.

As in cortical and hippocampal pyramidal neurons and BLA neurons (Power and Sah, 2002, 2005; Gulledge and Stuart, 2005; Hagenston et al., 2008), mGluRinduced, and likely $\mathrm{mAChR}$-induced, $\mathrm{Ca}^{2+}$ signaling in SPNs is entirely dependent on $\mathrm{IP}_{3}$-mediated $\mathrm{Ca}^{2+}$ release, boosted by CICR among neighboring $\mathrm{IP}_{3}$ Rs without recruiting $\mathrm{CICR}$ via RyRs. Both $\mathrm{IP}_{3}$ Rs and RyRs are involved in $\mathrm{mGluR}$-induced $\mathrm{Ca}^{2+}$ release in dopamine neurons; however, these two $\mathrm{Ca}^{2+}$ release mechanisms occur independently, being mediated by distinct intracellular second messengers, $\mathrm{IP}_{3}$ for $\mathrm{IP}_{3} \mathrm{Rs}$ and cyclic ADPribose for RyRs (Morikawa et al., 2003). Therefore, $\mathrm{IP}_{3} \mathrm{Rs}$ and RyRs generally exhibit functional segregation, although these two
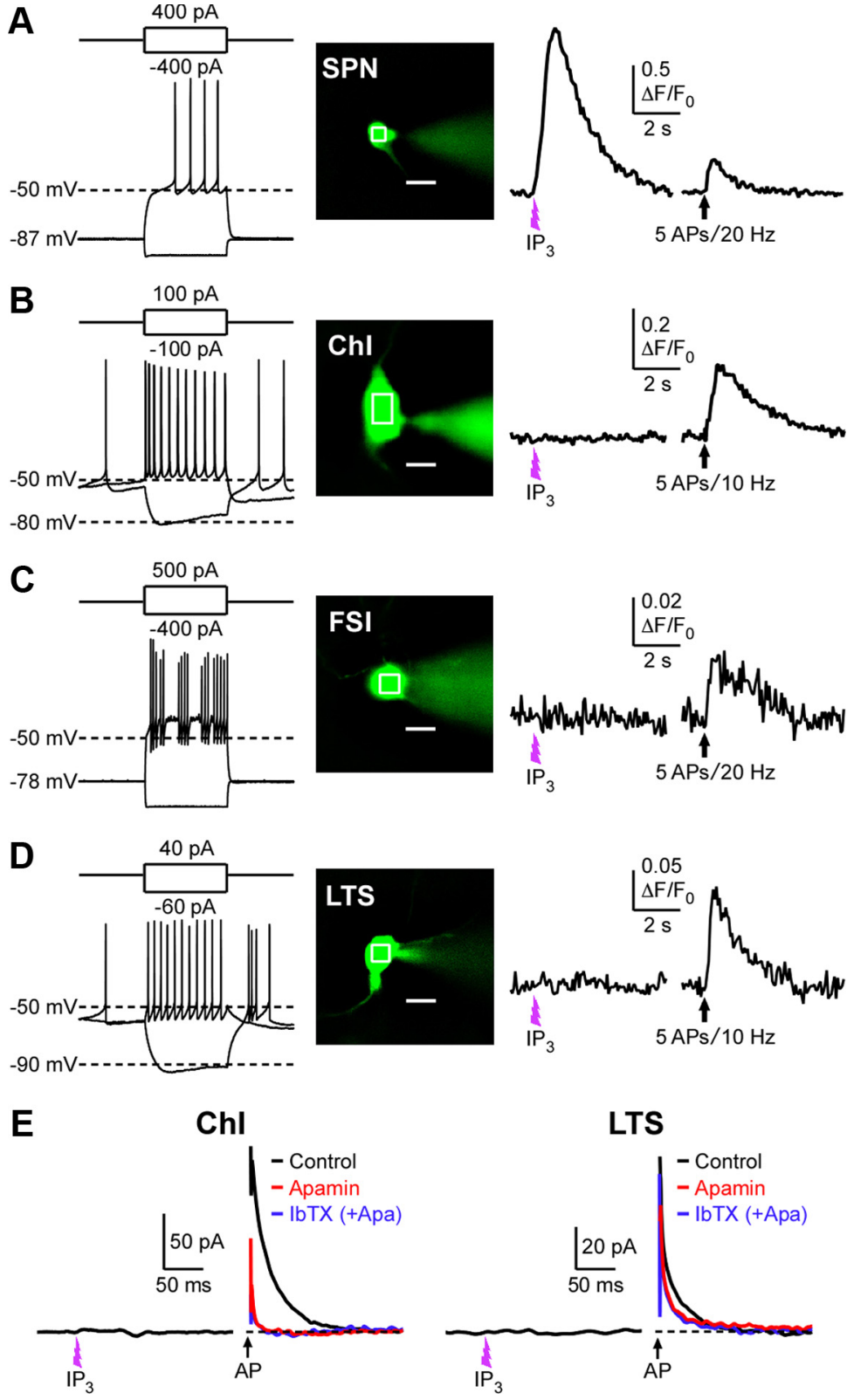

Figure 10. Photolytic application of $\mathrm{IP}_{3}$ produces $\mathrm{Ca}^{2+}$ transients only in SPNs among striatal neurons. $\boldsymbol{A}-\boldsymbol{D}$, Representative traces of $\mathrm{Ca}^{2+}$ transients evoked by flash photolysis of caged $\mathrm{IP}_{3}(400 \mu \mathrm{M})$ or trains of APs ( 5 APs at $10-20 \mathrm{~Hz}$; train onset at the arrow) in an SPN (A), a Chl (B), an FSI (C), and an LTS interneuron (D). Neuron types were identified by characteristic responses to depolarizing and hyperpolarizing current injections (500 ms) (Kawaguchi, 1993). Fluorescence changes were monitored at the ROls indicated in the images of cells filled with Fluo- $4(200 \mu \mathrm{m})$. Scale bar: $10 \mu \mathrm{m}$. Cells were voltage clamped at $-57 \mathrm{mV}$ in these experiments. $\boldsymbol{E}$, Example traces illustrating that photolytic application of $\mathrm{IP}_{3}$ failed to elicit outward currents in a Chl and an LTS interneuron, although these neurons exhibited apamin-sensitive (i.e., $S K$-dependent) $I_{\text {sAHP }}$ in response to unclamped APs $\left(V_{\mathrm{h}}=\right.$ $-57 \mathrm{mV}$ ). Error bars indicate SEM.

$\mathrm{Ca}^{2+}$ release channels have been shown to be coexpressed on the same pool of $\mathrm{Ca}^{2+}$ stores in all of these neurons, consistent with the idea that endoplasmic reticulum $\mathrm{Ca}^{2+}$ stores form a single continuous network in individual cells (Berridge, 1998). Functional segregation of $\mathrm{IP}_{3} \mathrm{Rs}$ and RyRs may, at least partially, be accounted for by their differential subcellular localization (Sharp et al., 1993).

$\mathrm{mGluR} / \mathrm{mAChR}$ activation also produces an inward current independent of $\mathrm{Ca}^{2+}$ release in SPNs. This most likely results from closure of KCNQ $\mathrm{K}^{+}$channels as a consequence of PLCdependent depletion of a membrane phospholipid, phosphati- 
dylinositol 4,5-bisphosphate (Shen et al., 2005). In contrast, photolytic application of $\mathrm{IP}_{3}$ causes a transient inward current, which is likely due to a TRPC-like cationic conductance activated by $\mathrm{Ca}^{2+}$ (Zhu, 2005). mGluR/mAChR-induced excitatory responses observed in many different neurons generally depend on either, or both, of these two ionic mechanisms (Fiorillo and Williams, 2000; Gulledge and Stuart, 2005; Canepari and Ogden, 2006; Hagenston et al., 2008; El-Hassar et al., 2011). The amount and spatiotemporal profile of $\mathrm{IP}_{3}$ achieved by $\mathrm{mGluR} / \mathrm{mAChR}$ activation appears to be insufficient to activate TRPC-like channels in SPNs.

\section{$\mathrm{Ca}^{2+}$ store dependence of slow AHPs}

BK and SK channels make distinct contributions to different phases of AHPs (Fakler and Adelman, 2008). Indeed, BK and SK channels contribute to fAHPs and sAHPs, respectively, in SPNs. Our data further demonstrate that sAHPs are largely dependent on intracellular $\mathrm{Ca}^{2+}$ release. $I_{\text {sAHP }}$ evoked by unclamped APs was augmented by caffeine, which increases $\mathrm{Ca}^{2+}$ sensitivity of RyRs, but unaffected by heparin, an $\mathrm{IP}_{3} \mathrm{R}$ antagonist. Thus, RyRdependent CICR triggered by AP-induced $\mathrm{Ca}^{2+}$ influx accounts for the $\mathrm{Ca}^{2+}$ store dependence of sAHPs, as in other neurons (Sah and McLachlan, 1991; Berridge, 1998; Kakizawa et al., 2007). This is also in line with the preferential localization of RyRs at the soma and proximal dendrites in SPNs (Martone et al., 1997), which display limited backpropagation of APs into distal dendrites (Day et al., 2008). However, AP-induced $\mathrm{Ca}^{2+}$ influx can trigger $\mathrm{IP}_{3} \mathrm{R}$-dependent $\mathrm{CICR}$ when $\mathrm{IP}_{3}$ levels are elevated by activation of mGluRs and other PLC-coupled receptors in cortical and hippocampal pyramidal neurons (Nakamura et al., 2000; Stutzmann et al., 2003), BLA neurons (Power and Sah, 2008), and dopamine neurons (Cui et al., 2007). It remains to be determined whether similar "cross talk" of AP-induced $\mathrm{Ca}^{2+}$ influx and $\mathrm{IP}_{3}$ signaling occurs in SPNs.

$I_{\text {sAHP }}$ had a small BK component, while the BK channel blocker IbTX failed to affect sAHPs. A small reduction in BKdependent sAHPs might be offset by IbTX-induced AP broadening, which would augment AP-evoked $\mathrm{Ca}^{2+}$ influx and subsequent SK channel activation. Based on differential sensitivity to EGTA and BAPTA, localized $\mathrm{Ca}^{2+}$ signaling around VGCCs is thought to drive BK channel activation that mediates AP repolarization and fAHPs (Fakler and Adelman, 2008). Our data suggest that the $\mathrm{Ca}^{2+}$ store-dependent component of sAHPs also involves highly BAPTA-sensitive, localized $\mathrm{Ca}^{2+}$ signaling, from RyRs to SK/BK channels and/or from VGCCs to RyRs, in SPNs (Fig. 7D).

\section{$\mathrm{IP}_{3}$-induced $\mathrm{Ca}^{2+}$ signaling selectively regulates SPNs in the striatum}

All SPNs showed robust responses to DHPG, muscarine, or $\mathrm{IP}_{3}$ applications. In contrast, striatal interneurons failed to respond to photolytic $\mathrm{IP}_{3}$ application using maximal UV intensity used in the present study, in agreement with an immunohistochemical study reporting selective expression of $\mathrm{IP}_{3} \mathrm{Rs}$ in SPNs among striatal neurons (Martone et al., 1997). To our knowledge, this is the first indication that functional $\mathrm{IP}_{3}$ signaling is specific to projection neurons in a given brain area, although we cannot completely rule out the possibility that striatal interneurons might express $\mathrm{IP}_{3}$ Rs with extremely low sensitivity.

SPNs fire clusters of APs interrupted by periods of pauses in vivo, sometimes without transition to a full DOWN state (Wilson and Kawaguchi, 1996; Stern et al., 1998). Firing pauses in distinct populations of SPNs are thought to be important for action se- lection and deselection (Jin and Costa, 2010; Krause et al., 2010). Working in concert with feedback and feedforward GABAergic mechanisms, robust $\mathrm{IP}_{3}$-mediated inhibition driven by glutamatergic and cholinergic inputs onto SPNs themselves might contribute to these pauses observed in behaving animals.

\section{References}

Berridge MJ (1998) Neuronal calcium signaling. Neuron 21:13-26. CrossRef Medline

Brasnjo G, Otis TS (2001) Neuronal glutamate transporters control activation of postsynaptic metabotropic glutamate receptors and influence cerebellar long-term depression. Neuron 31:607-616. CrossRef Medline

Canepari M, Ogden D (2006) Kinetic, pharmacological and activitydependent separation of two $\mathrm{Ca}^{2+}$ signalling pathways mediated by type 1 metabotropic glutamate receptors in rat Purkinje neurones. J Physiol 573:65-82. CrossRef Medline

Contant C, Umbriaco D, Garcia S, Watkins KC, Descarries L (1996) Ultrastructural characterization of the acetylcholine innervation in adult rat neostriatum. Neuroscience 71:937-947. CrossRef Medline

Cowan RL, Wilson CJ (1994) Spontaneous firing patterns and axonal projections of single corticostriatal neurons in the rat medial agranular cortex. J Neurophysiol 71:17-32. Medline

Cui G, Bernier BE, Harnett MT, Morikawa H (2007) Differential regulation of action potential- and metabotropic glutamate receptor-induced $\mathrm{Ca}^{2+}$ signals by inositol 1,4,5-trisphosphate in dopaminergic neurons. J Neurosci 27:4776-4785. CrossRef Medline

Day M, Wokosin D, Plotkin JL, Tian X, Surmeier DJ (2008) Differential excitability and modulation of striatal medium spiny neuron dendrites. J Neurosci 28:11603-11614. CrossRef Medline

Eggermann E, Bucurenciu I, Goswami SP, Jonas P (2012) Nanodomain coupling between $\mathrm{Ca}^{2+}$ channels and sensors of exocytosis at fast mammalian synapses. Nat Rev Neurosci 13:7-21. CrossRef Medline

Ehrlich BE, Kaftan E, Bezprozvannaya S, Bezprozvanny I (1994) The pharmacology of intracellular $\mathrm{Ca}^{2+}$-release channels. Trends Pharmacol Sci 15:145-149. CrossRef Medline

El-Hassar L, Hagenston AM, D’Angelo LB, Yeckel MF (2011) Metabotropic glutamate receptors regulate hippocampal CA1 pyramidal neuron excitability via $\mathrm{Ca}^{2+}$ wave-dependent activation of SK and TRPC channels. J Physiol 589:3211-3229. CrossRef Medline

English DF, Ibanez-Sandoval O, Stark E, Tecuapetla F, Buzsáki G, Deisseroth K, Tepper JM, Koos T (2012) GABAergic circuits mediate the reinforcement-related signals of striatal cholinergic interneurons. Nat Neurosci 15:123-130. Medline

Fakler B, Adelman JP (2008) Control of K(Ca) channels by calcium nano/ microdomains. Neuron 59:873-881. CrossRef Medline

Fiorillo CD, Williams JT (2000) Cholinergic inhibition of ventral midbrain dopamine neurons. J Neurosci 20:7855-7860. Medline

Fleig A, Penner R (2004) The TRPM ion channel subfamily: molecular, biophysical and functional features. Trends Pharmacol Sci 25:633-639. CrossRef Medline

Ghosh TK, Eis PS, Mullaney JM, Ebert CL, Gill DL (1988) Competitive, reversible, and potent antagonism of inositol 1,4,5-trisphosphateactivated calcium release by heparin. J Biol Chem 263:11075-11079. Medline

Gittis AH, Kreitzer AC (2012) Striatal microcircuitry and movement disorders. Trends Neurosci 35:557-564. CrossRef Medline

Goldberg JA, Wilson CJ (2005) Control of spontaneous firing patterns by the selective coupling of calcium currents to calcium-activated potassium currents in striatal cholinergic interneurons. J Neurosci 25:10230-10238. CrossRef Medline

Graybiel AM, Aosaki T, Flaherty AW, Kimura M (1994) The basal ganglia and adaptive motor control. Science 265:1826-1831. CrossRef Medline

Gubellini P, Pisani A, Centonze D, Bernardi G, Calabresi P (2004) Metabotropic glutamate receptors and striatal synaptic plasticity: implications for neurological diseases. Prog Neurobiol 74:271-300. CrossRef Medline

Gulledge AT, Stuart GJ (2005) Cholinergic inhibition of neocortical pyramidal neurons. J Neurosci 25:10308-10320. CrossRef Medline

Hagenston AM, Fitzpatrick JS, Yeckel MF (2008) MGluR-mediated calcium waves that invade the soma regulate firing in layer $\mathrm{V}$ medial prefrontal cortical pyramidal neurons. Cereb Cortex 18:407-423. Medline

Hikosaka O, Sakamoto M, Usui S (1989) Functional properties of monkey 
caudate neurons. III. Activities related to expectation of target and reward. J Neurophysiol 61:814-832. Medline

Hong M, Ross WN (2007) Priming of intracellular calcium stores in rat CA1 pyramidal neurons. J Physiol 584:75-87. CrossRef Medline

Hopf FW, Seif T, Mohamedi ML, Chen BT, Bonci A (2010) The smallconductance calcium-activated potassium channel is a key modulator of firing and long-term depression in the dorsal striatum. Eur J Neurosci 31:1946-1959. CrossRef Medline

Jin X, Costa RM (2010) Start/stop signals emerge in nigrostriatal circuits during sequence learning. Nature 466:457-462. CrossRef Medline

Kakizawa S, Kishimoto Y, Hashimoto K, Miyazaki T, Furutani K, Shimizu H, Fukaya M, Nishi M, Sakagami H, Ikeda A, Kondo H, Kano M, Watanabe M, Iino M, Takeshima H (2007) Junctophilin-mediated channel crosstalk essential for cerebellar synaptic plasticity. EMBO J 26:1924-1933. CrossRef Medline

Kawaguchi Y (1993) Physiological, morphological, and histochemical characterization of three classes of interneurons in rat neostriatum. J Neurosci 13:4908-4923. Medline

Khodakhah K, Ogden D (1995) Fast activation and inactivation of inositol trisphosphate-evoked $\mathrm{Ca}^{2+}$ release in rat cerebellar Purkinje neurones. J Physiol 487:343-358.

Krause M, German PW, Taha SA, Fields HL (2010) A pause in nucleus accumbens neuron firing is required to initiate and maintain feeding. J Neurosci 30:4746-4756. CrossRef Medline

Martone ME, Alba SA, Edelman VM, Airey JA, Ellisman MH (1997) Distribution of inositol-1,4,5-trisphosphate and ryanodine receptors in rat neostriatum. Brain Res 756:9-21. CrossRef Medline

McCray JA, Herbette L, Kihara T, Trentham DR (1980) A new approach to time-resolved studies of ATP-requiring biological systems; laser flash photolysis of caged ATP. Proc Natl Acad Sci U S A 77:7237-7241. CrossRef Medline

Mitrano DA, Smith Y (2007) Comparative analysis of the subcellular and subsynaptic localization of mGluRla and mGluR5 metabotropic glutamate receptors in the shell and core of the nucleus accumbens in rat and monkey. J Comp Neurol 500:788 -806. CrossRef Medline

Morikawa H, Imani F, Khodakhah K, Williams JT (2000) Inositol 1,4,5triphosphate-evoked responses in midbrain dopamine neurons. J Neurosci 20:RC103(1-5). Medline

Morikawa H, Khodakhah K, Williams JT (2003) Two intracellular pathways mediate metabotropic glutamate receptor-induced $\mathrm{Ca}^{2+}$ mobilization in dopamine neurons. J Neurosci 23:149-157. Medline

Nakamura T, Nakamura K, Lasser-Ross N, Barbara JG, Sandler VM, Ross WN (2000) Inositol 1,4,5-trisphosphate(IP3)-mediated $\mathrm{Ca}^{2+}$ release evoked by metabotropic agonists and backpropagating action potentials in hippocampal CA1 pyramidal neurons. J Neurosci 20:8365-8376. Medline

Nevian T, Sakmann B (2006) Spine $\mathrm{Ca}^{2+}$ signaling in spike-timingdependent plasticity. J Neurosci 26:11001-11013. CrossRef Medline

Nisenbaum ES, Wilson CJ (1995) Potassium currents responsible for inward and outward rectification in rat neostriatal spiny projection neurons. J Neurosci 15:4449-4463. Medline

Paquet M, Smith Y (2003) Group I metabotropic glutamate receptors in the monkey striatum: subsynaptic association with glutamatergic and dopaminergic afferents. J Neurosci 23:7659-7669. Medline

Pineda JC, Galarraga E, Bargas J, Cristancho M, Aceves J (1992) Charybdotoxin and apamin sensitivity of the calcium-dependent repolarization and the afterhyperpolarization in neostriatal neurons. J Neurophysiol 68:287-294. Medline

Ponzi A, Wickens J (2010) Sequentially switching cell assemblies in random inhibitory networks of spiking neurons in the striatum. J Neurosci 30: 5894-5911. CrossRef Medline

Power JM, Sah P (2002) Nuclear calcium signaling evoked by cholinergic stimulation in hippocampal CA1 pyramidal neurons. J Neurosci 22: 3454-3462. Medline

Power JM, Sah P (2005) Intracellular calcium store filling by an L-type calcium current in the basolateral amygdala at subthreshold membrane potentials. J Physiol 562:439-453. Medline

Power JM, Sah P (2008) Competition between calcium-activated $\mathrm{K}^{+}$chan- nels determines cholinergic action on firing properties of basolateral amygdala projection neurons. J Neurosci 28:3209-3220. CrossRef Medline

Sah P, McLachlan EM (1991) $\mathrm{Ca}^{2+}$-activated $\mathrm{K}^{+}$currents underlying the afterhyperpolarization in guinea pig vagal neurons: a role for $\mathrm{Ca}^{2+}$. activated $\mathrm{Ca}^{2+}$ release. Neuron 7:257-264. CrossRef Medline

Schoepp DD, Jane DE, Monn JA (1999) Pharmacological agents acting at subtypes of metabotropic glutamate receptors. Neuropharmacology 38 : 1431-1476. CrossRef Medline

Seidler NW, Jona I, Vegh M, Martonosi A (1989) Cyclopiazonic acid is a specific inhibitor of the $\mathrm{Ca}^{2+}$-ATPase of sarcoplasmic reticulum. J Biol Chem 264:17816-17823. Medline

Sharp AH, McPherson PS, Dawson TM, Aoki C, Campbell KP, Snyder SH (1993) Differential immunohistochemical localization of inositol 1,4,5trisphosphate- and ryanodine-sensitive $\mathrm{Ca}^{2+}$ release channels in rat brain. J Neurosci 13:3051-3063. Medline

Shen W, Hamilton SE, Nathanson NM, Surmeier DJ (2005) Cholinergic suppression of KCNQ channel currents enhances excitability of striatal medium spiny neurons. J Neurosci 25:7449-7458. CrossRef Medline

Stern EA, Jaeger D, Wilson CJ (1998) Membrane potential synchrony of simultaneously recorded striatal spiny neurons in vivo. Nature 394:475478. CrossRef Medline

Stutzmann GE, LaFerla FM, Parker I (2003) $\mathrm{Ca}^{2+}$ signaling in mouse cortical neurons studied by two-photon imaging and photoreleased inositol triphosphate. J Neurosci 23:758-765. Medline

Surmeier DJ, Ding J, Day M, Wang Z, Shen W (2007) D1 and D2 dopaminereceptor modulation of striatal glutamatergic signaling in striatal medium spiny neurons. Trends Neurosci 30:228-235. CrossRef Medline

Tepper JM, Wilson CJ, Koós T (2008) Feedforward and feedback inhibition in neostriatal GABAergic spiny neurons. Brain Res Rev 58:272-281. CrossRef Medline

Walker JW, Feeney J, Trentham DR (1989) Photolabile precursors of inositol phosphates. Preparation and properties of 1-(2-nitrophenyl)ethyl esters of myo-inositol 1,4,5-trisphosphate. Biochemistry 28:3272-3280. CrossRef Medline

Wilson CJ, Kawaguchi Y (1996) The origins of two-state spontaneous membrane potential fluctuations of neostriatal spiny neurons. J Neurosci 16 : 2397-2410. Medline

Witten IB, Lin SC, Brodsky M, Prakash R, Diester I, Anikeeva P, Gradinaru V, Ramakrishnan C, Deisseroth K (2010) Cholinergic interneurons control local circuit activity and cocaine conditioning. Science 330:1677-1681. CrossRef Medline

Womack MD, Khodakhah K (2003) Somatic and dendritic smallconductance calcium-activated potassium channels regulate the output of cerebellar Purkinje neurons. J Neurosci 23:2600-2607. Medline

Wu J, Shih HP, Vigont V, Hrdlicka L, Diggins L, Singh C, Mahoney M, Chesworth R, Shapiro G, Zimina O, Chen X, Wu Q, Glushankova L, Ahlijanian M, Koenig G, Mozhayeva GN, Kaznacheyeva E, Bezprozvanny I (2011) Neuronal store-operated calcium entry pathway as a novel therapeutic target for Huntington's disease treatment. Chem Biol 18:777793. CrossRef Medline

Yan J, Aldrich RW (2010) LRRC26 auxiliary protein allows BK channel activation at resting voltage without calcium. Nature 466:513-516. CrossRef Medline

Yan J, Aldrich RW (2012) BK potassium channel modulation by leucinerich repeat-containing proteins. Proc Natl Acad Sci U S A 109:7917-7922. CrossRef Medline

Yan Z, Flores-Hernandez J, Surmeier DJ (2001) Coordinated expression of muscarinic receptor messenger RNAs in striatal medium spiny neurons. Neuroscience 103:1017-1024. CrossRef Medline

Zhu MX (2005) Multiple roles of calmodulin and other $\mathrm{Ca}^{2+}$-binding proteins in the functional regulation of TRP channels. Pflugers Arch 451: 105-115. CrossRef Medline

Zucchi R, Ronca-Testoni S (1997) The sarcoplasmic reticulum $\mathrm{Ca}^{2+}$ channel/ryanodine receptor: modulation by endogenous effectors, drugs and disease states. Pharmacol Rev 49:1-51. Medline 